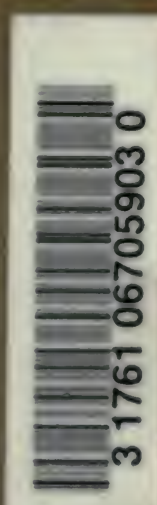




Digitized by the Internet Archive in 2007 with funding from Microsoft Corporation 
66

LELAND STANFORD JUNIOR UNIVERSITY PUBLICATIONS

UNIVEIRSITY SERIES

\section{A Morphological Study of some members of the Genus Pallavicinia}

or

DOUGLAS HOUGHTON CAMHPELL:

PROFESSOR OF BOTANY

$A N B$

FLORENCE WILLIAMS

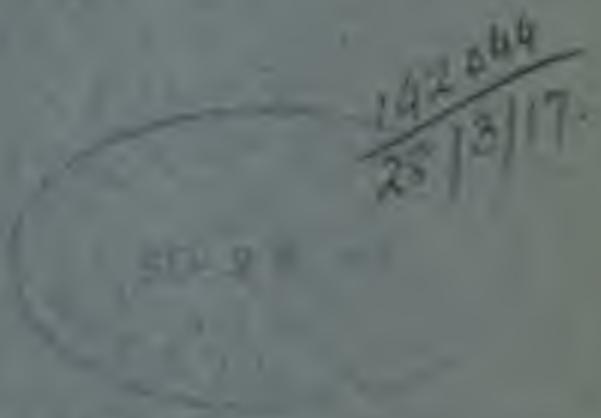




\section{UNIVERSITY SERIES}

INocertabce is SrLxworses, I. Vernon Lyman Kcllogg. Proiessor of Endomology. 89 yp. 4 plates. 1008 . Price $\$ 1,00$.

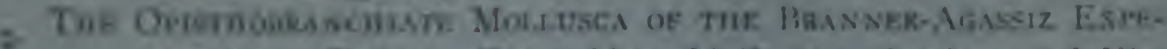
grow to Benzil- Frank Mace McFarland. I'rofessor of Histology. $1050 \%$. 21) plates. 1900). Price, \$roo.

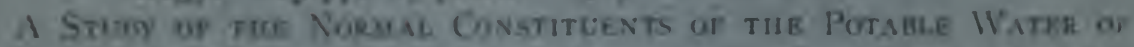
ros San Frincisco Peninsuila. John Pearce Mitchell, Assitant Proiesnor of Chenistry. To pp., I map. Igro. Price, 500.

Syrossts of ane True Crans (Bracitiera) of Monterey Bay, Ciliroxsia. Frank Walter Weymouth. 64 PP., 14 plates. 1910 Price, 5oc.

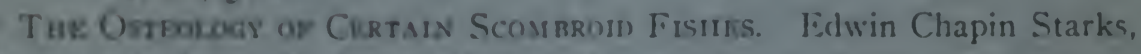
Assistant Proiessor of Zoology. 49 pp., 2 plates, I text figure. 1911. Price, 50c.

6 A Pursical. Timeny of Eiffetrification. Fermando Sanford, Professor of Phyics 60 pp, 2 plates. 19I1. Price, $50 \mathrm{C}$.

If Tue Matzke Mrsoricl. Voluarc. Papers by John Ernst Matzke, late Professor of Romanic Languages, and Thirteen Colleagues. I62 PI. I9II. Price, \$1.00.

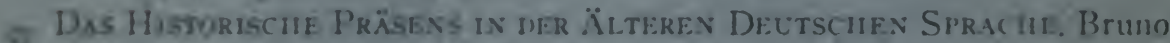
Boezinger, Acsistant Professor of Germanic Languages. nf PP. 1912. Price, 50c.

The EFFET af a Strictiy Vegetarle Diet oN the SinNtineous

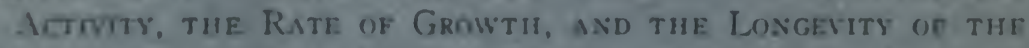
Alsuvo Rit. James Rollin Slonaker. Assistant Professor of Physiology. $36 \mathrm{pp}, 1$ plate, 15 text figures. 1912. Price, $50 \mathrm{c}$.

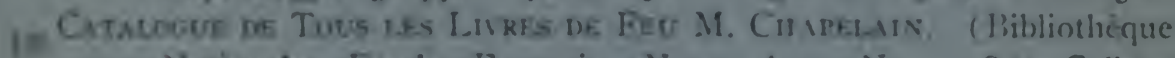
Nationale, Fonds Français, Nouv. Acq.. No. 318.)-Colbert Sesrles. Associate Professor of Romanic Langruages. II Pp., 2 plates, 1012. Price, $75 \mathrm{C}$.

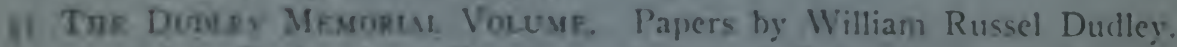
late Proiesuor of Botany, and Several Colleagues. 1.37 pp.. i2 text figures, 9 plates. 1913. Price, Si.oo.

Tus Ersous or ture Stunpord Exuenition to Brazil. Edwin Chapin Starks, Assistant Professor of Zoology. 77 PP., 15 plates. 191.3 Price, 75c. 
. 

LELAND STANFORD JUNIOR UNIVERSITY PUBLICATIONS UNIVERSITY SERIES

\title{
A Morphological Study of some members of the Genus Pallavicinia
}

\author{
BY \\ DOUGLAS HOUGHTON CAMPBELL \\ PROFESSOR OF BOTANY \\ AND \\ FLORENCE WILLIAMS
}

WITH TWENTY-THREE FIGURES

[Issued April 30, 1014]

STANFORD UNIVERSITY, CALHFORNIA

PUBLISHED BY THE UNIVERSITY

1914 
$14 i$

Staxpord UNIVERSitY

Press 


\title{
A MORPHOLOGICAL STUDY OF SOME MEMBERS OF THE GENUS PALLAVICINIA
}

\author{
BY \\ DOUGLAS HOUGHTON CAMPBELL. \\ AND \\ FLORENCE WILLIAMS
}

Introduction.

CONTENTS

Pallavicinia (Mittenia) Zollingeri (Gottsch.) Schiffner.

Pallavicinia radiculosa (Sande) Schiffner.

Pallavicinia Levieri Schifiner.

The Antheridium.

Spermatogenesis.

The Archegonium.

The Embryo.

Spore Division.

Summary.

Conclusions.

Bibliography.

\section{INTRODUCTION}

The Liverworts, probably the most primitive of existing land-plants, offer many important morphological problems to the botanist. Among the Liverworts, no group is more interesting than that known usually as the Anacrogynous Jungermanniales, or, as less commonly denominated, the Metzgeriaceac.

While a good deal of work has been done upon the morphology of these plants, notably the important investigations of Leitgeb $[1]$ and Goebel $[1,2]$ as well as the earlier studies of Hofmeister [1] and others. the minute study of their structure and development has been confined to a comparatively small number of species: and iursher investigations on 
some of the less known forms must be done before it will be possible to determine the relationships of the different genera of the Anacrogynae.

At present the classification of the Anacrogynae is in a most unsatisfactory condition, and it is certain that radical changes must be made in the scope of certain genera, and in the grouping of the families as they are at present constituted.

Most of the Anacrogynae are plants of relatively simple structure, being thallose forms for the most part, although in certain genera, $c . g$., Blasia, Fossombronia. Treubia, leaf-like marginal lobes are present; and the transition from the typically thallose Anacrogynae to the much more numerous leafy liverworts (Jungermanniales acrogynae) is by no means an abrupt one.

During a stay in Western Java, in 1906, a number of rare liverworts were collected, including several species of Pallavicinia. Among these were three which have been seldom collected, and which so far as we know have never been critically examined as to their anatomy and development. As it was thought that a careful study of these species might be of value for a better understanding of the morphology of the genus, the specimens were given to Miss Williams for investigation. The making of the preparations upon which the present paper is based, as well as most of the drawings, are the work of Miss Williams.

The genus Pallavicinia as understood by Schiffner [I], comprises the two old genera, Mörkia and Blyttia, of Gottsche. In his recent excellent résumé of the Liverworts, Cavers [2] has expressed the opinion that these older genera should be revived, and the name Pallavicinia be discarded. Should this view be accepted, all of the species here consided would be transferred to the genus Blyttia, unless the sub-genus Mittenia is separated as a distinct genus.

Most of the species of Pallavicinia are found in the moist tropics, being especially abundant in the more elevated regions. Several species, however, $c_{\text {. }}$.. P. Lyellii, occur in the more humid parts of the temperate zones.

Stephani, in his review of the Hepaticae [I], recognizes 29 species of Pallavicinia, which are placed in two sections: Procumbentes, ${ }^{1}$ with 20 species, and Dendroideae, with 9. In the Procumbentes (Eupallavicinia) the plant is a prostrate thallus (Fig. I, $B$ ), usually attached for its whole length to the substratum by numerous rhizoids. The members of the section Mittenia have the thallus differentiated into two parts, a prostrate rhizome-like

'The section procumbentes = Schiffner's sub-genus Eupallavicinia.

The Dendroideae $=$ Mittenia Gottsch. 
region, nearly or quite destitute of a lamina, and upright branches which grow from the rhizome. In these upright shoots, the lamina is broadly expanded and repeatedly forked. These dichocomously tranclied shoots resemble very closely the leaven of eertain small ferni, especially the $\mathrm{Hy}$. menophyllaceac (Fig. $1, A$ ).

Of the three species to be discussed in the present paper, $\{w 0, P$, radiculosa and $P$. Lenieri, belong to the section Eupallavicinia, the third, $P$. Zollingeri, to Mittenia.

The general structure of the thallus is much the same in all species. Except for the rhizome-like portion occurring in some species, the thallas is differentiated into a very distinct midrib, several cells thick, and a dellcate lamina, or wing. on each side of the midrib, these marginal wing being always in Eupallavicinia but a single cell in thickneas; but in Mitzenia they merge more or less gradually into the midrib. The midrib is traverned throughout its extent by a strand of conducting tiswue comproted of cells which are narrowed and greatly elongated, pointed at the ends. and with thick pitted walls.

Branching is of two types. In the first ehere is an appareat diclastomy, the equal branches having their midribs and conducting tianues continusous with those of the main shoot. The second type of branclving has the appearance, superficially. of exogenous adventitions branches occurring on the ventral surface of the midrib. In these ventral chents the conducting tissue is not connected with the midrib of the main showe (Fig. 2, $A, B$ ).

Rhizoids oceur more or less abundantly on the lower surface of the thallus where it is in contact with the substratum.

All of the species are dioceious, the reproductive ongans being borne upon the dorsal surface of the thallus. The antheridia, which are prontected by scales, occur either upon the midrib or close to it. The archegonia are in definite groups which are surrounded by a double envelope, the outer one forming the "involucre." the inner envelope a more or lest tuhular sheath, the "perianth." 


\section{METHODS}

Most of the material was killed with a $1 \%$ aqueous solution of chromic acid. Other material was fixed with alcohol containing $10 \%$ acetic acid. Larger specimens were also preserved in commercial alcohol. The material was imbedded in paraffin, cut uniformly $6 \mu$ in thickness, cleared in xylol, and stained variously for the study of different structures. Bismarck-brown proved the best stain for the vegetative parts of the thallus, except the conducting tissue, which was well differentiated by gentian-violet. The latter stain was also found useful in the study of the spermatozoids. These were not satisfactorily stained with either safranine or methyl violet. Haidenhain's iron-alum-haematoxylin proved much the best stain for the nuclei, and was well differentiated by either Bismarck-brown or Delafield's haematoxylin.

\section{Pallavicinia (Mittenia) Zollingeri (Gottsh.) Schiffner.}

Pallaricinia Zollingeri is one of the most striking members of the genus, and has hitherto been collected only from Java and Sumatra. The specimens here described were collected near the summit of Mt. Pangerango, an extinct volcanic cone in Western Java, nearly 10,000 feet in height. In this region the plant is very abundant, especially on the low banks along the trail, where it occurs in dense mats of considerable size. It fruits abundantly, and no trouble was experienced in securing an abundant supply of material in various stages of development. In May, 1913, the plant was found on Mt. Banajao, near Manila; and probably the same species was also found in the Benguet mountains. So far as we know, this is the first record of its occurrence outside Java and Sumatra. It grew at a height of about 2,000 metres, under much the same conditions as on Pangerango in Java.

From the slender, creeping rhizome the delicate fan-shaped erect shoots, which are about $6 \mathrm{~cm}$. in height, arise, vivid green in color, and, as we have already stated, resembling so closely a delicate fern that they might very well be mistaken for it (Figs. 1, 5).

The method of growth is sympodial, the apex of the prostrate main axis turning upward, and developing into the expanded, leaf-like erect shoot. From the ventral side of the shoot, near the base, a branch develops which grows horizontally for a time, as a rhizome, and finally turns upward to form another upright frond.

The growth of the shoot is due to the activity of a single large apical cell (Fig. 3, $A, B$ ). This appears broadly triangular in section, with seg- 
ments cut off from two of its surfaces. Sections through young shoots whose appices are just turning upward, showed in one case five apical cells, of which it was imposaible to say which was the origimal one. Some of the initial cells had not yet divided, while in otheri one or more segments had been ert off. The original apex continues its growth upward. while these secondary initial cells are left betind, but later they may give rise to ventral shoots.

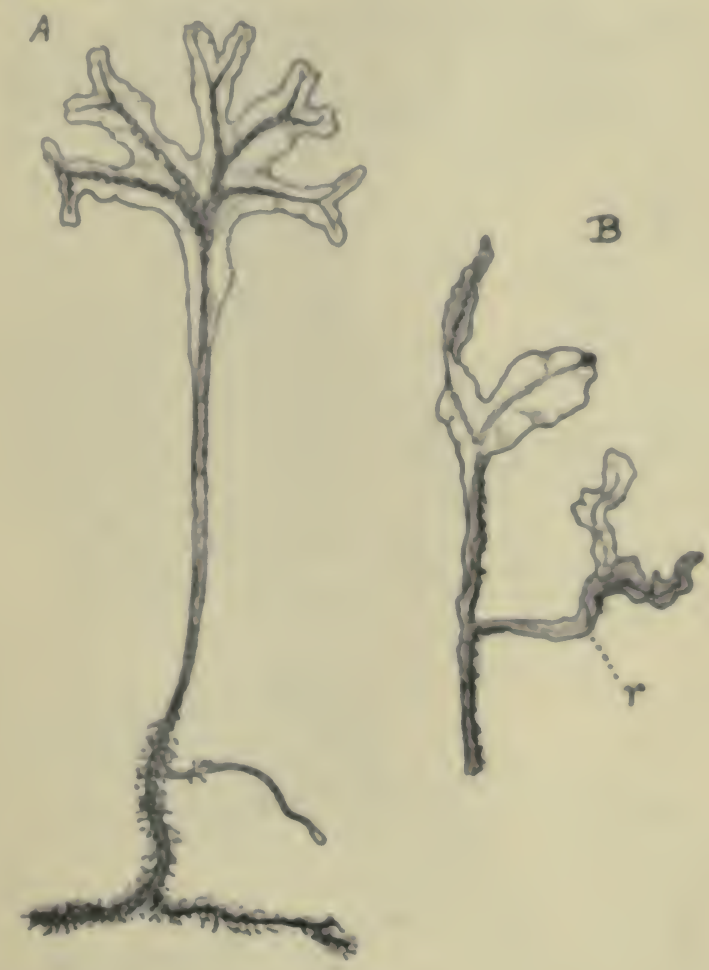

Fig. 1.

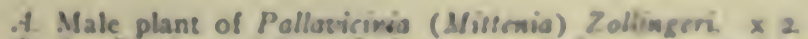

$B$. Sterile plant of $P$ rodirwloso, natural sise: ", ventral branch.

One of these secondary apical cells begins active growth and gives rise to the shoor which continues the sympodium. It grows horiaontally for a time, but funally turns upward and develops into the next upright green frond. Several segments are eut off from the apical cell before a differentiation of the different tiscues of the shost is apparene. Finally the midrib and lateral wings can be distinguished, and in the former the central strand of elongated cells appears. Thus, at the base of the shoot. 
the conducting tissue is absent, and there is no connection between it and that of the older shoot from which the branch has arisen (Fig. 2, B).

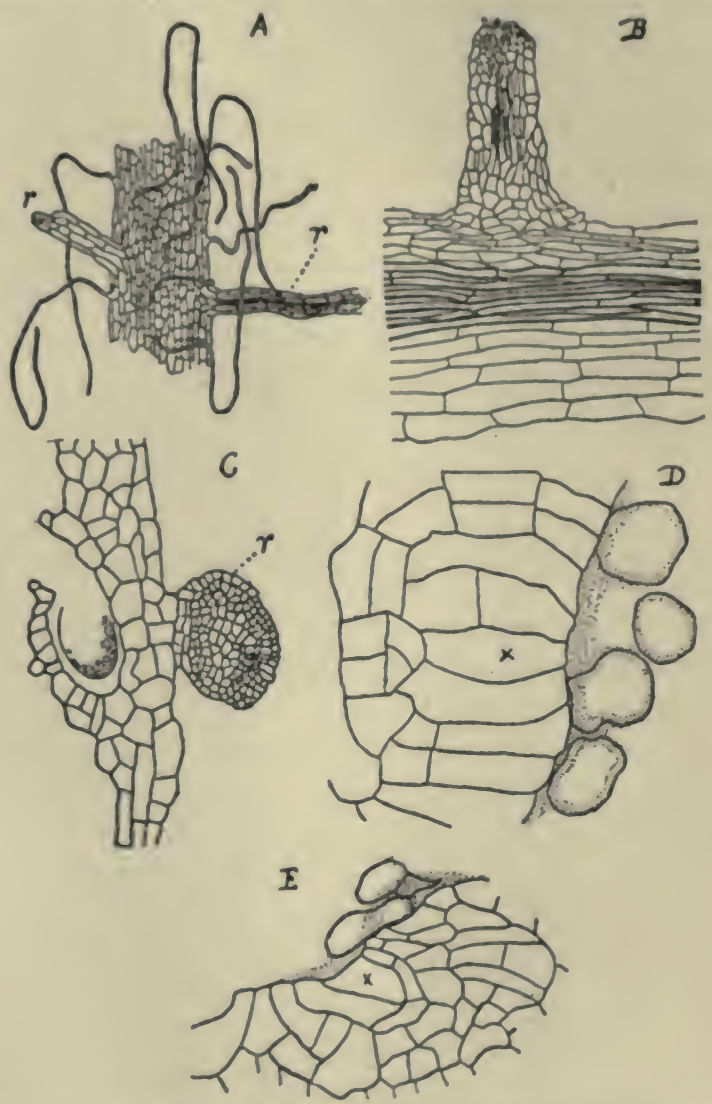

Fig. 2. Pallavicinia Zollingeri.

A. Part of the basal region of a frond, showing rhizoids, and two ventral branches, $r$.

B. Median longitudinal section of the base of a shoot passing through a young ventral branch. The conducting tissue of the main shoot and the branch are not continuous.

C. A ventral shoot $(r)$ growing from the surface of the frond of an antheridial plant. The remains of an antheridium may be seen upon the dorsal surface.

$D$. The apical region of the shoot shown in $C . x$, the apical cell.

E. Apical region of a ventral shoot.

The other initial cells may never develop beyond cutting off a small number of segments. These groups of cells may be recognized for a long time on the surface of the shoot, near its base. Sometimes, however, one or more of these cell-groups resume activity, and from them 
arise the slender, apparently adventitious branches which are often met with upon the ventral side of the shooth. These slender cylindrical rootlike branches may be only a few cells in thickness, and are traversed by a conspicuous strand of conducting tisure, which can easily be traced to the base of the shoot, where it ends abruptly, and doen not join the corresponding strand of the main axis. The occurrence of ventral branctie: is confined mainly to the prostrate portion of a shoot, or to the base of the stalk of the frond. They may, however, oceanionally arike from the ven. tral side of the expanded portion of a frond, and in the only ease observed (Fig. 2, G) the shoot was much broader than those ariding from the stalk of the frond of from the prostrate rhizome. The frond from which this shoot arose bore entpty antheridia.

The apical cell of $P$. decipiens, a species from Ceyton, strongly resembling $P$. Zollingeri in general appearance, has been carefully atudied

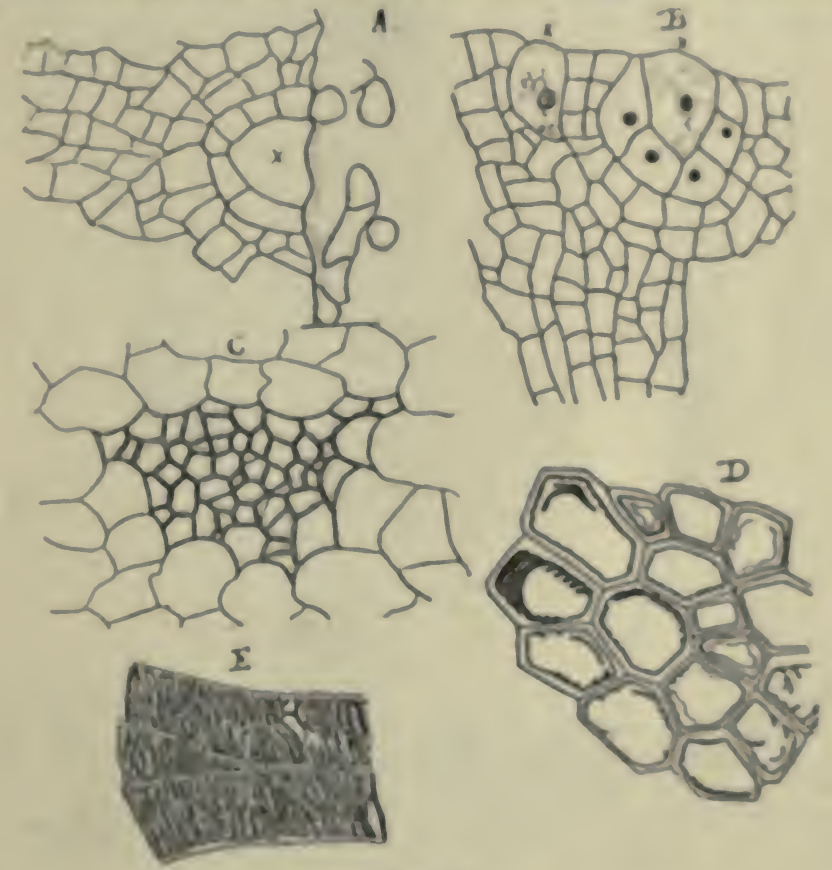

Fig 3.

1. Vertical section of the erowing point of a frond acgenent of Pallaticinw Zolliwgeri.

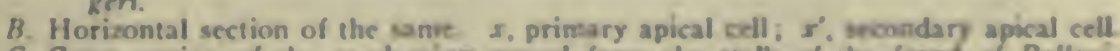

C. Cross-section of the conducting niand from the stalk of the frond of Pellosi. rivia Zollingern.

$D$. Some of the conducting cells, more hichly magnified.

E. Longitudinal section of conducting cells. 
by Farmer [1]. In this species the form of the apical cell is quite different from that of $P$. Zollingeri. It has the form of a three-sided prism. Four sets of segments are formed, three lateral and one basal, instead of the two sets of lateral segments found in $P$. Zollingeri.

Long, slender, simple rhizoids which are developed from the superficial cells, are formed in great numbers upon the prostrate rhizomes. Here and there occur isolated scales, one cell in thickness, and very much like those which cover the antheridia.

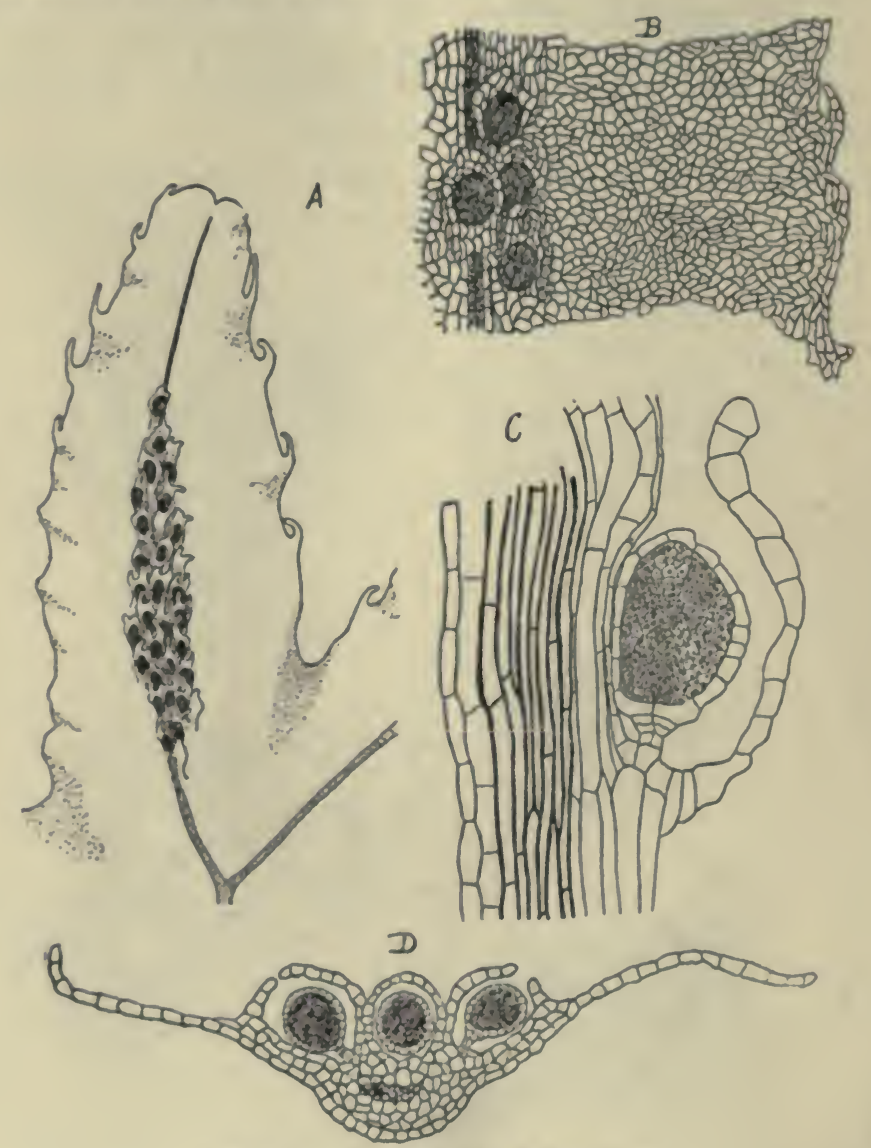

Fig. 4. Pallavicinia Zollingeri.

A. Segment of the frond of an antheridial plant, $x 25$ (about).

$B$. A portion of $A$, more highly magnified.

C. Longitudinal section of the shoot, passing through an antheridium, and showing the strand of conducting tissue.

$D$. Cross-section of a segment of the frond, showing the position of the antheridia on the dorsal surface of the midrib. 
The cells of the ventral part of the tridtrib have thick walle in which are pits elongated transversely. These pits are in lines extending round the cell, and forming partial spirals, this being perhaps due to the longtudinal growth of the cell (Fig - 3, D, E). These cells, which are presumably conducting cells, have very little protoplaimic conterts, thut agreeing with Tansley's description of the corresponding tisue in other members of the genus $\{1\}$. The cells of the eortical tissue af the rhizome contain many starch granules, in this respect recalling Caverv' fingures of Môrkic flost'ostrima [2].

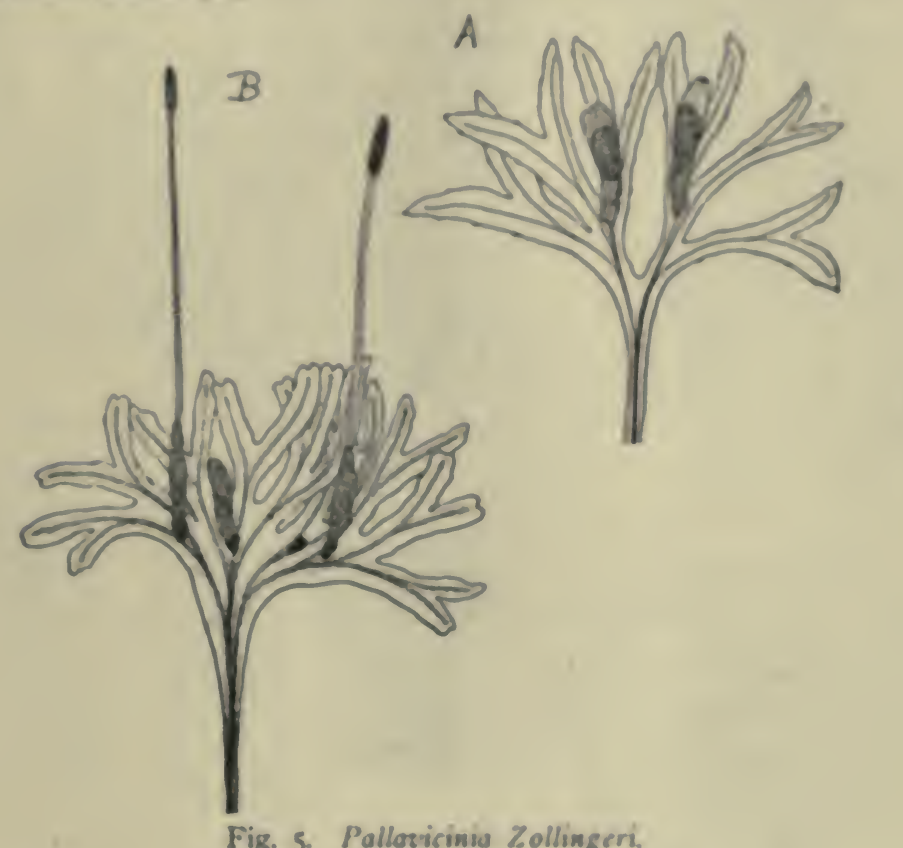

Two fronds of female plants $\times 2$.

The base of the acrial shoot, or frond, like the rhizone of which it is the continuation, is quite clestitute of the wing-like lamina found in the expanded portion of the frond. The eylindrical stalk, as it ascends, becomes gradually flattened dorsi-ventrally and develops a narrow wing on either side which widens until it forms the beginning of the expanderd. fan-shaped lamina of the frond. The first dichotomy aceurs when the young frond is $3.4 \mathrm{~cm}$. in height. The forking is repeated from two :0 four times, and there thus results the palnuately divided leaf-like shoot, the slender central strands of the delicate segments simulating almost exactly the venation of a true leaf. In the archegonial plants these fan-shaped 
fronds are about $2.5 \mathrm{~cm}$. in width (Fig. 5). In the male plants they are somewhat smaller. The apex of each segment is indented, and the margin is wavy, with conspicuous teeth, or narrow lobes, which are usually pointed and hooked (Fig. 4, A).
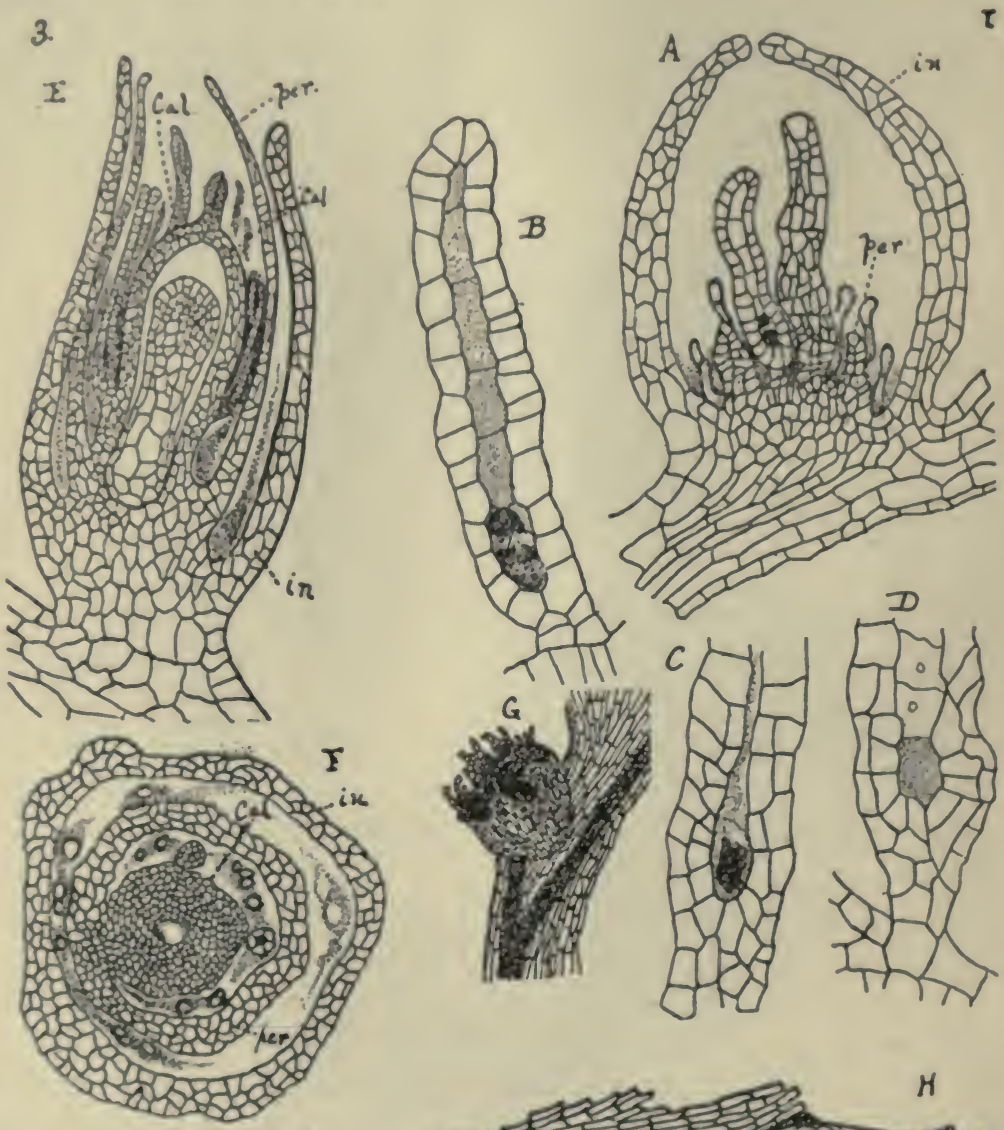

4.

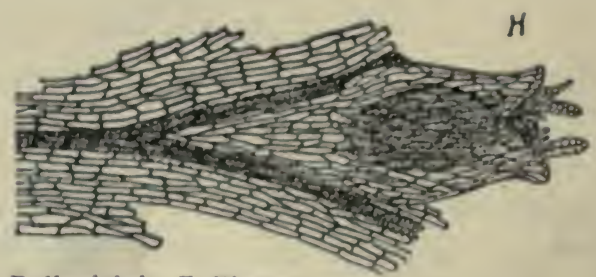

Fig. 6. Pallavicinia Zollingeri.

A. Median section of an archegonial receptacle; in, involucre; per, perianth. B. A nearly mature archegonium.

$C, D$. Ventral part of two old archegonia.

E. Receptacle containing an embryo; cal. calyptra.

F. Transverse section of a similar receptacle.

G, H. Archegonial receptacles. 
The male plant (Fig. I, A) is smaller and more delicate than the female, while the lamina is more strongly corrugated. The antheridia oceur in thick patches upon the doral surface of the midrits of the ultimate segments of the frond, and each antheridiun is subtended by a scale whose margins may be either entire or toothed (Fig. 4. A, B). More than one crop of antheridia may be formed on a frond, and one sometimes finds old patches of scales with the remains of divcliarged antheridia on the older portion of the frond whose terminal segments bear younger antheridia. Fig. 4, D shows a cross-section of a segunent of the frond, passing through a group of antheridia upon its dorkal surface. Fig. 4, C shows a longitudinal section of a frond-segment, passing through a nearly ripe antheridium, covered by its subtending scale.

The archegonial receptacles (Fig. $6, C, H$ ) arise very clone th the point where two segments of the frond diverge, and not infrequently actually at the fork. although not as a marginal structure. As the receptacle grows it overlaps the fork; but careful examination shows that it does not arise from the margin, but from a point some distance from it between two of the costae. Several arehegonial receptacles niay oceur on a single frond, and always near the base of the lamina. Receptacles of quite different ages oceur in close proximity, so apparently the development is not necessarily acropetal. The material was too old to show the young archegonia, and for the present the question as to the exact origin of the young receptacle must remain in doubt.

\section{Pallavicinia radiculosa (Sande) Schiffner}

Pallaricinia radiculosa is the largest species of the genus. and a most striking liverwort. The specimens used in these investigations were collected at Tjipanas, some remarkable hot springs on M. Pangerango, at an elevation of 2140 metres. The plants grow in large loose mats where the warm water oozes out of the mountain side. Tjipanas is the original locality for the species, and it has been collected at this place by a number of botanists. Schiffner states $[2]$ that it is also known from Borneo, and Stephani [1] gives also a station in the Island of Mergui in the Bay of Bengal. It was collected in January. 1913. by Professor Campbell near Taiping in the Federated Malay States, growing upon a dripping bank, under much the same conditions as in Java, except that the location was only a few hundred feet above sea level instead of at an elevation of 2000 metres. The difference is to be explained by the fact that in Java the necessary heat was furnished by the hot springs abou: which it was growing. It is highly probable that further search will show the plant to eccur in other parts of the Malayan region. 
The plant has an elongated prostrate thallus with a thick and very conspicuous midrib (Figs. $7, A, 8, E$ ). The thallus may reach a length of upwards of $20 \mathrm{~cm}$. with a width of $7 \mathrm{~mm}$. The thallus is usually forked and is attenuated posteriorly, due to the gradual suppression of the lamina. The midrib itself is practically of equal diameter throughout, and projects strongly on the ventral side. As already stated, the wings of the thallus become gradually narrower toward the base of the

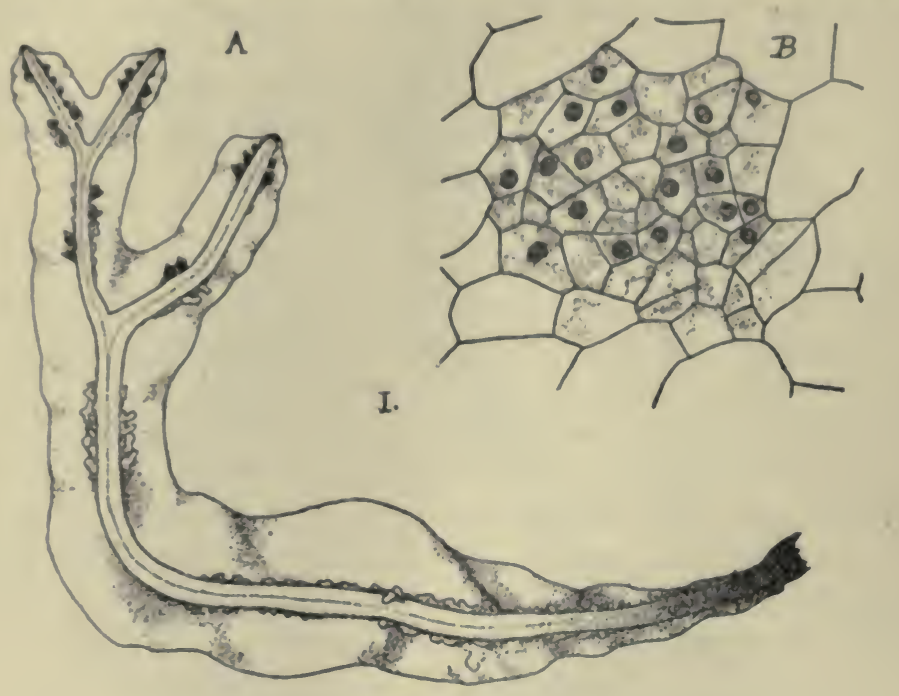

2.

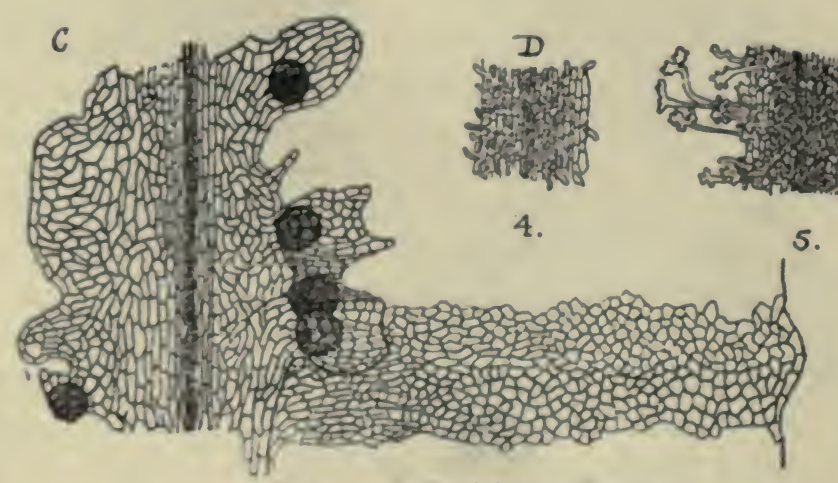

Fig. 7. Pallavicina radiculosa.

A. Male plant, $\times 3$.

$B$. Cross-section of young conducting tissue, very highly magnified.

C. Midrib of the thallus, showing the position of the antheridia.

$D$. Young; $E$, older rhizoids. 
shoot, and finally almost completely disappear, so that the oldest pan of the shoot is almost perfectly cylindrical. The surface of the wings is smooth and the margin undulate, but not develoging lobes or teeth, in this respect differing from $P$. Zollingeri.

The ventral surface of the midrib is completely covered by short papillate hairs, like the true rhizoids, outgrowths of single kupericial cells. These papillac become longer in the older parts of the thallus, and gradually give place to the long, dark purple-red rhizoids, which in the basal region form a dense mass. These conspicuous rhiroide (Fig. 7. $D, E)$ are composed of a single cell, but develop a number of short branches at the apex. As in $P$. Zollingeri ventral, apparently adven. titious branches are developed which much resemble the main shoots, but are somewhat smaller. It is highly propable, however, that under favor. able circumstances these develop into perfectly normal plants. Their origin was not investigated, but it is probable that they arise in much the same way as the similar branches in P. Zollingeri.

Quite frequently the wings of the thallus are attenuated anteriorly as well as posteriorly, and as a result the apex of the shoot is somewhat pointel. In form and size the male and female plants are very similar.

The amheridia form a row on each side of the midrib, and are arranged in elongated groups separated by sterile areas (Fig. 7. A). They are attached to the side of the midrib and project laterally, but are directed slightly forward. They are covered by broad scales, one cell in thickness, which arise at intervals behind an antheridium and, passing above it, extend along the side of the midrib as a shelf-like projection. These scales are deeply incised, scalloped, and sometimes toothed, varying much in size and shape. The scales may subtend a single antheridium or a small group. Sometimes no antheridium is formed under a seale (Fig. 7, C). The antheridia arise in strictly acropetal succession, and the scales near the apex cover immature antheridia only.

The female plants (Fig. 8, E) closely resemble the males, except for the different appearance of the reproductive organs. The arehegonial receptacles resemble those of $P$. Zollingeri, but are much langer. They arise at various points upon the dorsal surface of the midrib, but there is no connection between their formation and the branching of the thallus. They possess the conspicuous perianth and involucre characteristic of the other members of the genus. The archegonia are much more numerous than in either of the other species examined. The involucre, also, is more conspicuous, having a decply incised spreading margin, which is strongly revolute. 
The growing point of the shoot lies at the bottom of a more or less evident notch, formed by the active growth of the tissue on each side of the apical cell. The latter has segments cut off only from its two lateral faces. Seen in horizontal section (Fig. 8, C) it is a narrow triangle, with
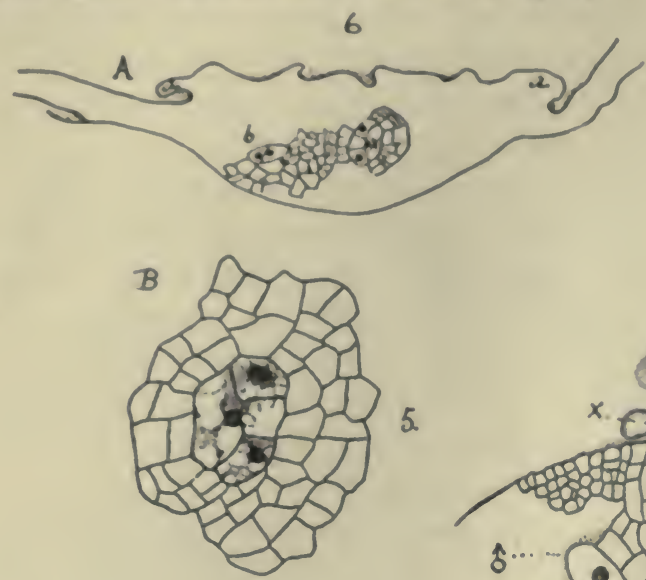

5.
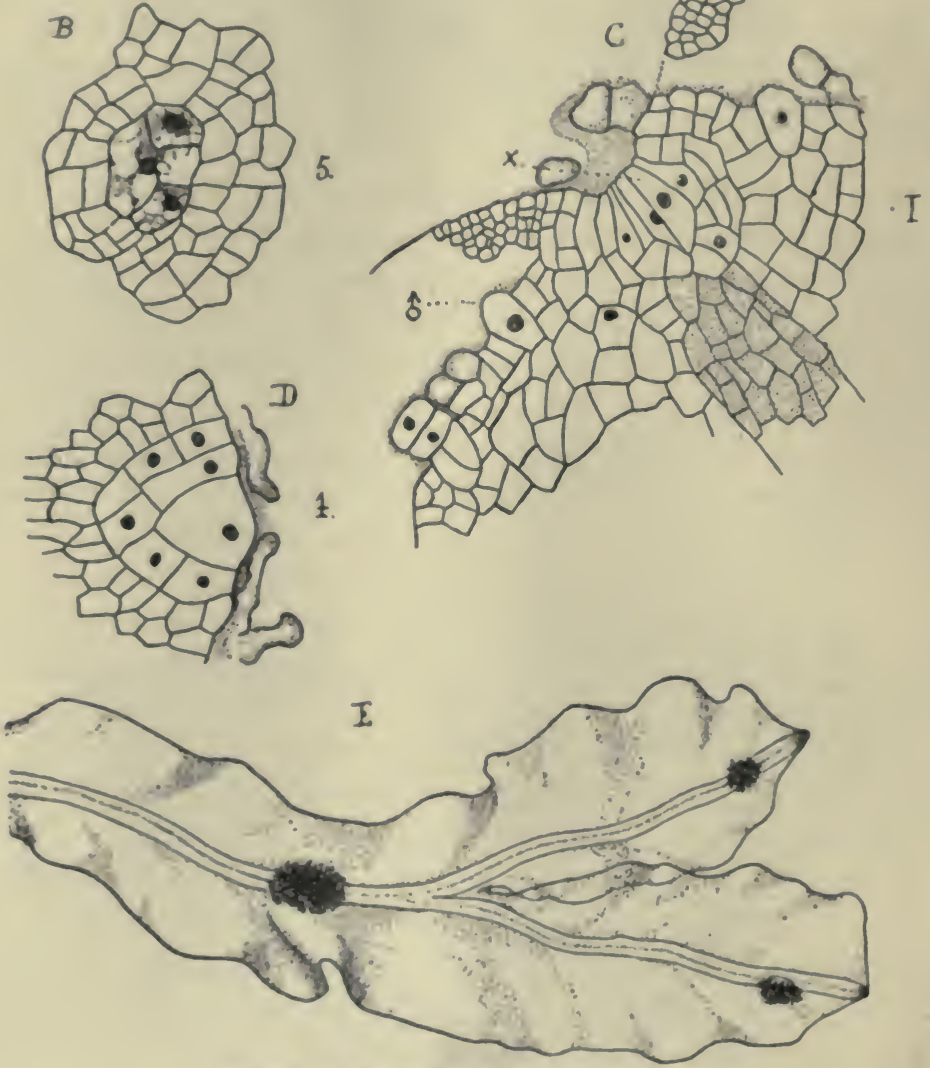

Fig. 8. Pallavicina radiculosa.

A. Cross-section of the thallus apex, showing the apical cell, $x$, and the apex, $b$, of $a$ branch. $a, a$ are the young scales subtending antheridia.

$B$. The apex of the shoot, more highly magnified.

$C$. Horizontal section of the shoot apex, showing the apical cell, $x$, and a very young antheridium.

$D$. Vertical longitudinal section of the apex.

E. Archegonial plant, $\times 3$. 
the sides converging somewhat in front. In vertical longitulinal section it appears also triangular, but very much broader (Fig. 8, D). A eross. section (Fig. $8, A, B$ ) shows that the lateral faces meet above and below at an acute angle, so that the whole cell has somewhat the form of a triangular welge, with the edges directed respectively donally and ren. trally. The segments cut off from the lateral faces are large, and ordinarily are formed alternately right and left. Before a dichototny occurs, however, more than one segment may be cut off succevively on one side, and one of these presumably gives rise to the apical cell of the new branch, the branching being in the strict sense of the word not a true dichotomy.

In horizontal and vertical longitudinal sections the arrangement of the segments derived from the apical cell is much the same. In crosssection the elongated, almost oval cell appears surrounded by the crescent. shaped segments (Fig. 8, A, B). Fig. 8, A shows a cronsection of the thallus apex shortly after the dichotomy is complete, and the growing point of the new branch is established. The lobes $a, a^{\prime}$, are the beginning of young antheridial scales, while the group of cells, b, it the growing point of the new branch. The divisions of the apical cell are not in quite the same plane as those of the original apex.

Fach segment eut off from the apical cell first divides transveriely into an adaxial and an abaxial cell. The latter cell divides only by walls perpendicular to the plane of the thallus, and contributes to the wing or lamina of the thallus, which remains permanently but a single cell in thickness. The adaxial cell divides crosswise into a middle and an inner cell. The fonner forms the outer tissues of the midrib, and also from it arise the antheridia. The innermost cell, by subsequent repeated longitudinal divisions, gives rise to the narrow cells of the conducting strand traversing the midrib. These cells at first have dense contents. which later mostly disappear. A section of the young conducting strand is shown in Fig. $7, B$.

The entire apex of the shoot, and the younger antheridia, are bathed in mucilage which is secreted by two-celled glandular hain developed from the outer cells of the young segments; and similar mucilage secreting hairs are also found among the antheridia.

\section{Pallavicinia Levieri Schiffner}

Pallaricinia Lesieri. the third species considered here, is much less restricted in its distribution. It is quite common in the neighborthood of Tjiboclas in Java, at an elevation of $1400-1500$ metres, and material was collected at several points. It has been reported from several other sta- 
tions in Java and Sumatra, and according to Stephani occurs also in the Pacific Islands, Tahiti and Hawaii. It will probably be found in other parts of Polynesia.

The plant (Fig. 9) is smaller than $P$. radiculosa, and there is much more difference in size between the male and female plants.

Like $P$. radiculosa, the thallus is prostrate. It usually occurs on the trunks of trees, anong other liverworts and mosses, and does not form masses of large size. The plants are very delicate in texture, and the male plants are noticeably smaller than the females or the sterile plants. They

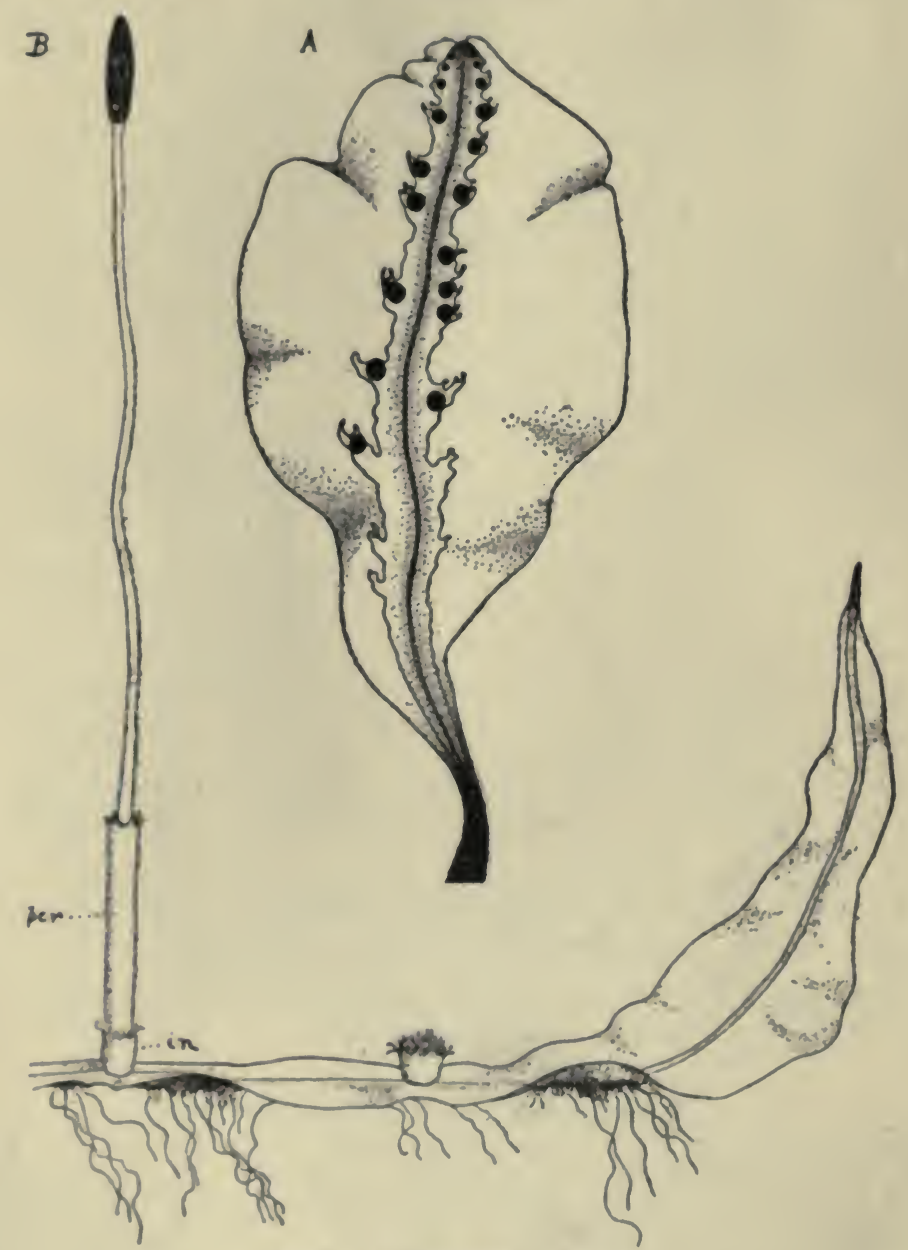

Fig. 9. Pallavicinia Levieri.
A. Male plant, $\times 8$.
B. Female plant, $\times 4$. 
measure only about $2 \mathrm{~cm}$. in length and $4-5 \mathrm{mim}$, in width. The fernale plants (Fig. 9, B) are about $10 \mathrm{~cm}$. in length and $7 \mathrm{~mm}$. wide.

The wings of the thallus are relatively very wide, and as usual but one cell thick. They are waved slightly on the margin, which is estire except for an oceasional cell which projects slightly so as 20 form an incon. spicuous tooth. Anteriorly the lamina of the astheridial plasut narrows abruptly to the apex of the shoot, which is iudented. The midrib projects strongly on the ventral sicle. The rhizoids are much less nunierouss than in $P$. radiculoso, and quite different iu color, being a rather light brown. instead of the deep purple-red found in $P$. radiculoso. The conducting strand of the midrib is much like that of $P$. radicmloso.

From the sicles of the midrib in the male plant extend a series of scales which form a more or less continuous shelf-like structure. These scales have their free margins deeply lobed and toothed, and underneath the shelf formed by these confuent scales the antheridia occur, either singly or in groups of several together ( Fig. 9, A). The antheridia arike in acropetal succession, and are arranged in a somewhat broken row along each side of the midrib. They are more completely covered by the wattending scales than is the case in $P$. radiculosa, and are not so evidently divided into groups separated by sterile areas.

The antheridia, to judge from a somewhat cursory examination, appear to agree in all essential details of structure with those of $P$. radiculosa.

The apical cell of the thallus is not so deeply placed as in $P$. radicw. losa, but a study of horizontal and vertical sections shows that it has the same form. On the ventral surface of the midrib in P. Levieri, as in $P$. radiculosa, there may occasionally be found small groups of meristematic cells, which appear dormant, and do not show a definite apical cell. The smaller groups are slightly sunken: the larger ones, perhaps having resumed activity. form hemispherical protuberances. The origin and development of these groups of cells is apparently the same as the similar ones in P. Zollingeri, and probably under favorable conditions these give rise to normal branches.

The archegonial plants of $P$. Letreri (Fig. 9, B), besides being much larger than the male plants, show also a very different appearance at the apex of the shoot. There is no indentation at this point, but the thallus is prolonged ino a nearly cylindrical process of some length, in which the wings are quite suppressed. It is possible that an examination of a langer number of individuals might show that this difference in apices of the male and female plants is not constant. The rhizoids of the female plan:s 
of $P$. Levieri were much longer than those of either of the other species that were studied, sometimes reaching a length of a centimeter or more The archegonial receptacles are smaller than those of $P$. radiculosa, and are more like those of $P$. Zollingeri.

\section{The Antheridium}

Of the three species examined, $P$. radiculosa was the best for the study of the young antheridium, as most of the stages of development were found in the material.
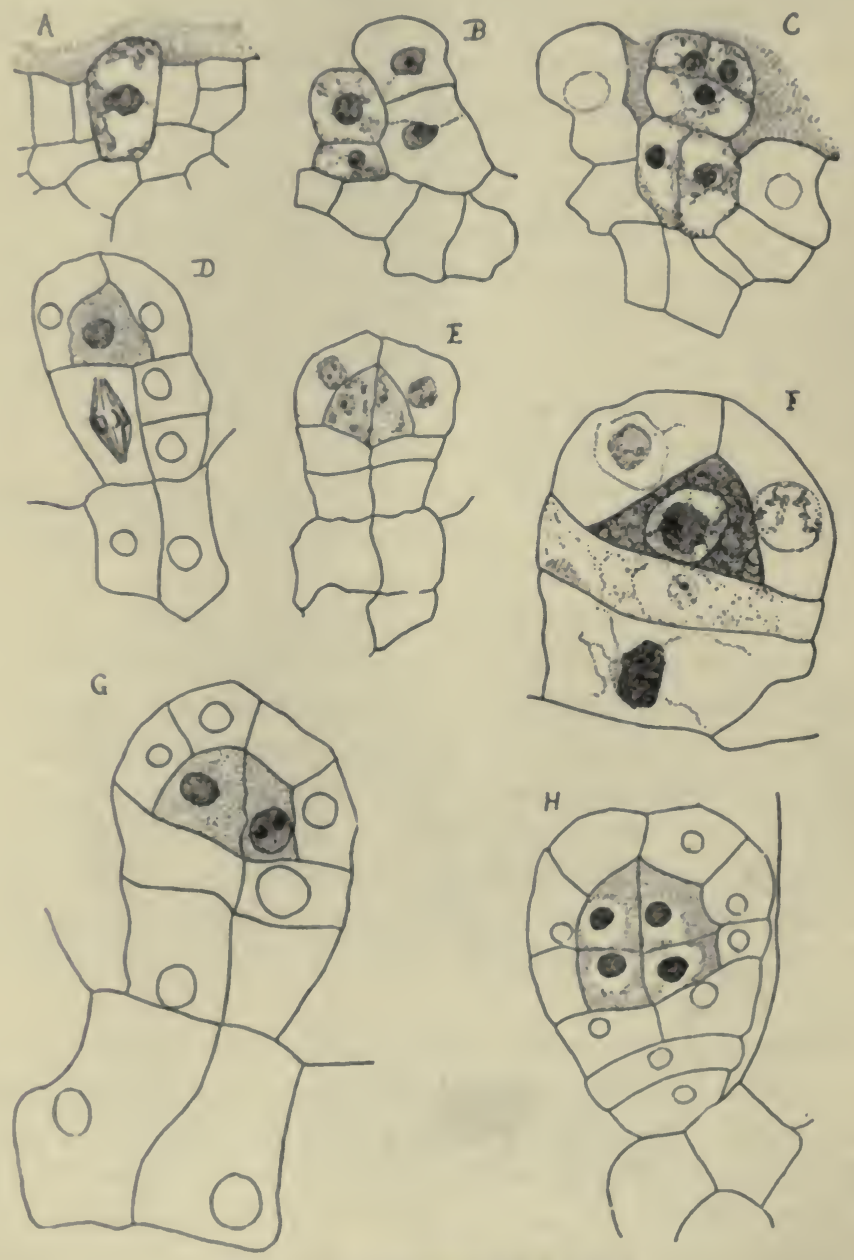

Fig. 10. Pallavicinia radiculosa.

Early stages in the development of the antheridium.

Longitudinal sections. $D, F$, are cut in a plane at right angles to $E, G$. 
The young antheridium arises very near the apex of the thallus, as a single large cell, projecting from the sicte of the midrib (Fig. 10, A). The first division wall is transverne, and separates a bacal cell which takes no part in the development of the antheridium itself, and an ouster cell, which is the real mother-cell of the antheridium (Fig, 10, B) As about the same time that this transverte division is formed in the young antheridium, certain neighboring superficial cells of the wivib become evident, which later form special structures accontpanying the antheridia. Some of these "companion cells" socrete the mucilage which bathet the young antherictia; while others, not always readily distinguishable from the earliest stages of the antherictia themselves, finally develop into the characterivtic scales covering the older amheridia, sonsewhat 2 ilescribol by Caupbell [1] for Ancura.

The divisions in the antheridium show some variation. Of the two cells formed by the first iransverse wall, the inner one divides by a vert:cal wall into two cells, which remain sunk in the midrib and usually divide no further (Fig. 10, C-E), and may usually be recognized at the base of the stalk in the fully developed antheridium.

The first wall in the antheridium itself is also transverse. Of the iwo cells thus formed, the lower gives rise to the stalk of the antheridium. and also to the layer of cells separating the sperm-cells from the stalk of the antheridium. The outermost of the two original cells divides first by a median vertical wall, and each of these cells is next divided by a nearly peri. clinal wall into two very unequal cells. This wall intersects both the ousside wall of the antherictim and the median wall. and is quickly followet by a second similar wall which meets the first one and also intersects the median wall. A cross-section of the antheriditum at this stage (Fig. 18. A) shows two triangular central cells surrounded by four narrow peripheral ones. The young antheridiun at this stage closely resembles that of Porella Bolanderi (Camplell [1]. Fig. 52), and differs from the :ısual type of the Jungernamniales, where, according to leitgeb ([1], II. p. 44) these two peripheral cells do not extend to the top of the anther. idium, and a third peripheral cell is cut off before the separation of the central cell is complete. The appearance of longitudinal sections of the young anthericlium, cut respectively in the plane of the first median wall, and at right angles to it, are shown in Fig. 10, D, G, E. H. Cross-sections of similar stages are shown in Fig. 11, A. C. The next divisions take place in the peripheral cells, and in the stalk, the two primary spermatogenous cells remaining undividet until the stalk is well developed and 
the four original peripheral cells of the antheridium have each divided at least once (Fig. 10, G). The first division in the central cells is a transverse one, quickly followed by a vertical division, so that whether in longitudinal- or cross-section, the central cells are arranged quadrant-wise (Figs. 10, $H$, ir,$B)$. The subsequent divisions follow rapidly, but without any
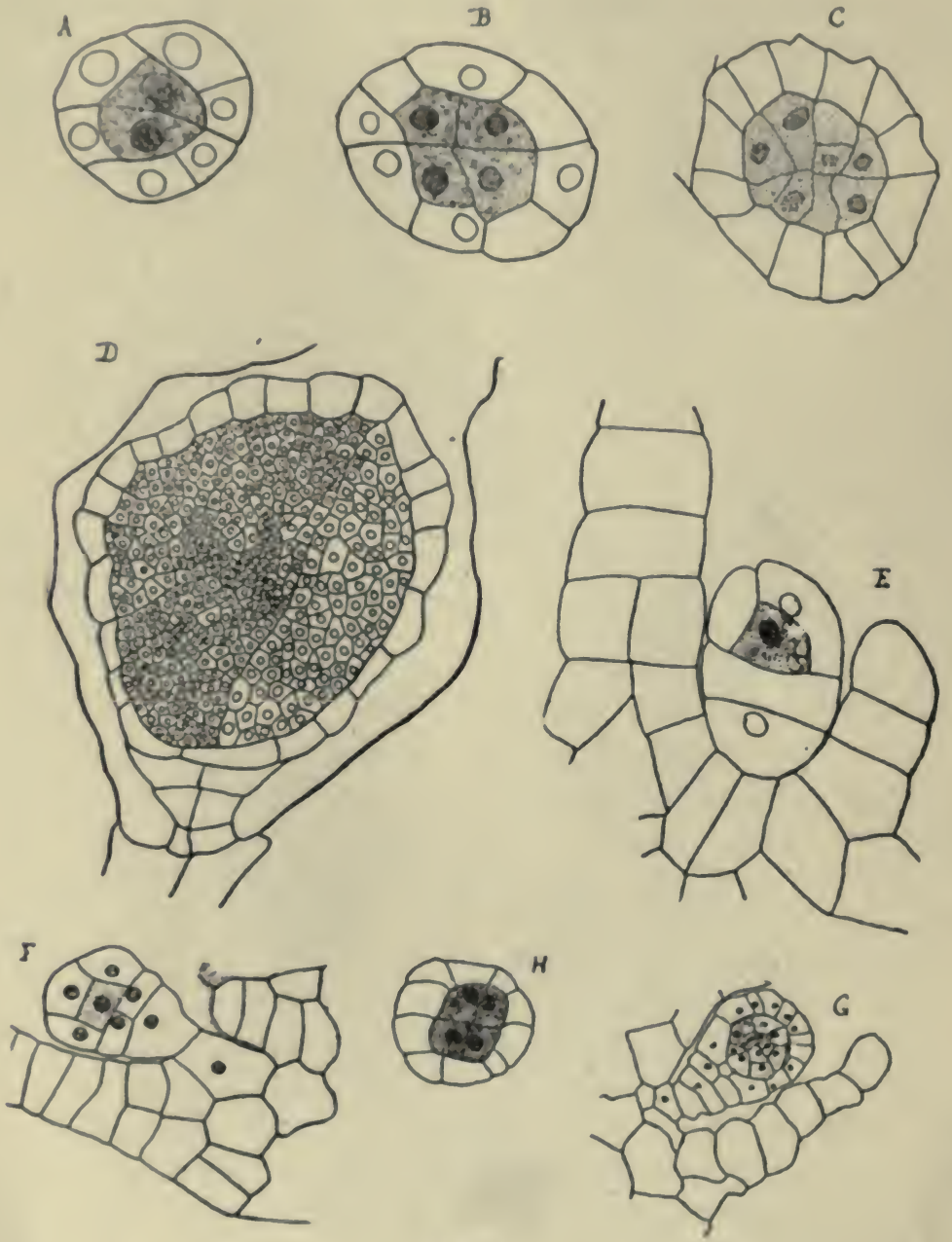

Fig. 11.

$A-D$. P. radiculosa; E-G, P. Levieri.

A-C. Cross-section of young antheridia.

$D$. Longitudinal section of a nearly ripe antheridium.

E-G. Longitudinal sections; $H$, transverse section. 
definite succession being evident. There is but little displacernent of the original division-walls, so that up to the last divison of the sperm-cells the limits of the earlier divivions can be plainly traced, and the spermatocytes are in irregular blocks marking the early divisione. While within these blocks of cells the nuclei are usually in the kame stage of mitotit. each segment of the antheridium may show a different rtage of nucleas division. This was also noted by Humphrey in his study of Fossombromio longiseta [1].

\section{Spermatogenesis}

Pallaricinia Zollingeri proved the best species for a atudy of spermatogenesis, and the investigation of this subject was mainly devoted to that species. In the earliest stages procurable the final mitosis had taken place, and the two resulting nuclei had begun to assume the elongated form found in the completed spermatozoid (Fig. 12, A, B). The final mitosis is accompanied by the formation of a delicate but perfectly evident division wall separating the pair of spermatocytes. The spermatocytes at this stage closely resemble those of Colycularia radiculaso (Campbell [2], Fig. 7 ). The length of the young spermatocyte in $P$. Zollingeri is about $7 \mu$. Fig. 12. A, shows the pair of spermatocytes at this stage. The blepharoplast (bl.) now has the form of a somewhat curved rod at the end of the elongated nucleus. Sometimes the blepharoplatis of the pair of spermatocytes are at the same end, sometimes at opposite ends. With the development of the spermatozoid, the blepharoplast, as usual, elongates rapidly, and becomes a slender curved rod. hooked at the free apex, and following the curve of the elongating nueleus which becomes crescent-shaped, with the anterior end more or less conspicuously attenuated (Fig. 12, $D-K$ ). In some of the preparations there was present between the blepharoplast and the anterior part of the sperm-nucleus a thick, rod-shaped body, which perhaps represents the "Nebenkörper" described by Ikeno [1] in Marchantia. The cilia arise from the blepharoplast a short distance back of the apex, and become finally about as long as the body of the free spermatozoid, which is about 16 i in length.

The development of the spermatozoid in $P$. rodiculosa was found to be so much like that of $P$. Zollingeri that no attempt was made to follow it in detail. However, some of the later stages in the last mitosis of the spermatocyte, which were not seen in $P$. Zollingeri, were secured in $P$. radiculosa. The nuclei are so small that difficulty was experienced in determining the number of chromosomes, which is prohably eight (see Fig. 12, N-Q). The spermatocytes are separated, as in $P$. Zollingeri, by a delicate membrane, which is nore diffeult to demonstrate 


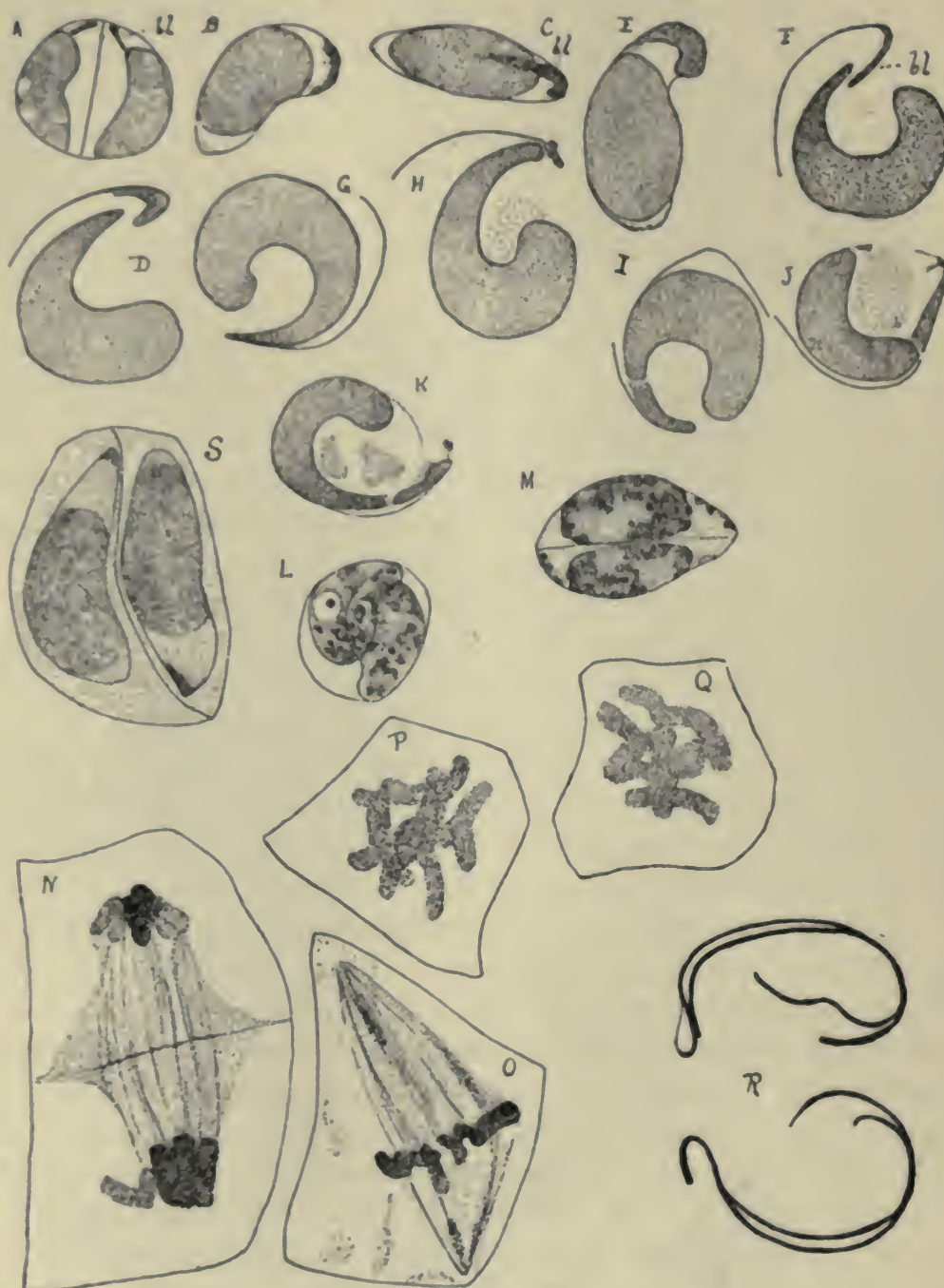

Fig. 12.

A-M. Spermatogenesis in Pallaricinia Zollingeri.

L. Pair of spermatocytes seen from above.

M. Similar spermatocytes seen in profile.

$N$, O. Last mitosis in the spermatocytes of Pallazicinio radiculoso.

$P-Q$. Polar view.

$R$. Spermatozoids of $P$. Zollingeri.

$S$. Pair of spermatocytes of $P$. Levieri.

All magnified about 2,000 times. 
than in that species. The best differentiation was secured by Haiden. hain's iron-alum-haematoxylin. The blepharoplans could not be made out, but presumably are present.

A sufficient study of the spermatogenesis in $P$. Levieri was mate to show that it is very much like that in the other two species. Fig. 12, S. shows the pair of spermatocytes with the keparating membrane and the blepharoplasts. The spermatocytes are somewhat larger than corresponding stages in P. Kollingeri, neasuring aboust $\mathrm{gt}$ in length.

\section{The Archegonium}

In all species of Pallavicinia the archegonia are in groupt aurrouncled, as already stated, by a double envelope: an outer one, the mrolucre, much the more conspicuous before the fertilization of an archugennium; and an inner one, which is very smalt at first, but which after an cmbryo is formed grows rapidly and forms a conspicuous tubular sheath enclosing the developing sporophyte.

In P. Zollingeri, the involucre is cup-shaped, with a lobel margin (Fig. $6, G, H$ ). Within this, and surrounding the base of the archegonial group, is the young perianth, which at this stage does not reach above the level of the venter of the archegonia (Fig. 13). P. radiculosa (Fig. 13. $A, B, E)$ differs from $P$. Zollingeri mainly in the tmuch greater number of archegonia in the receptacle, and in the more faring and deeply fringed involucre. $P$. Letieri is somewhat intermediate in character, both as to the number of archegonia and the form of the involucre (Fig. 13. D).

The receptacle is at first level with the surface of the thallus, but as new archegonia develop it becomes raised and forms a more or less prominent elevation, or placenta, to which the archegonia are attached (Fig. 13. E).

Of the three species examined, $P$. radiculosa was the best for the study of the archegonium, as all stages of development were present in the material. P. Leiveri also showed most of the stages, but as it differed very little from $P$. radiculoso an exhaustive study was not made. None of the specimens of $P$. Zollingeri showed very young archegonia, but to judge from the few immature archegonia that were seen it does not diffeessentially from the other species.

Pallaricivia radiculosa, while agreeing in the main with other anacrogynous Jungermanniales. in the development of the archegonium shows certain differences that may be noted.

The youngest archegonia (Fig. 14, A, C) show a stalk composed of two or three cells, and a terminal, approximately hemispherical cell from 
which the archegonium itself is developed. In this terminal cell, as in all Hepaticae, three nearly vertical, intersecting walls are formed, surrounding an axial cell. In longitudinal sections two of the peripheral cells are seen, with the axial cell between $(B, C)$; in cross-section, the axial cell appears triangular in shape $(F)$.

The young archegonium as it grows in length becomes divided into two stories, by a transverse wall in each cell, and this first transverse division separates the basal part, or venter, from the neck. In the three peripheral cells, or more commonly in only two of them, a longitudinal division is formed, so that the axial cell is surrounded by five rows of peripheral ones. In the ventral region, other longitudinal walls are formed subsequently, but in the neck region no further longitudinal divisions occur, and a cross-section of the neck shows a central cell surrounded by
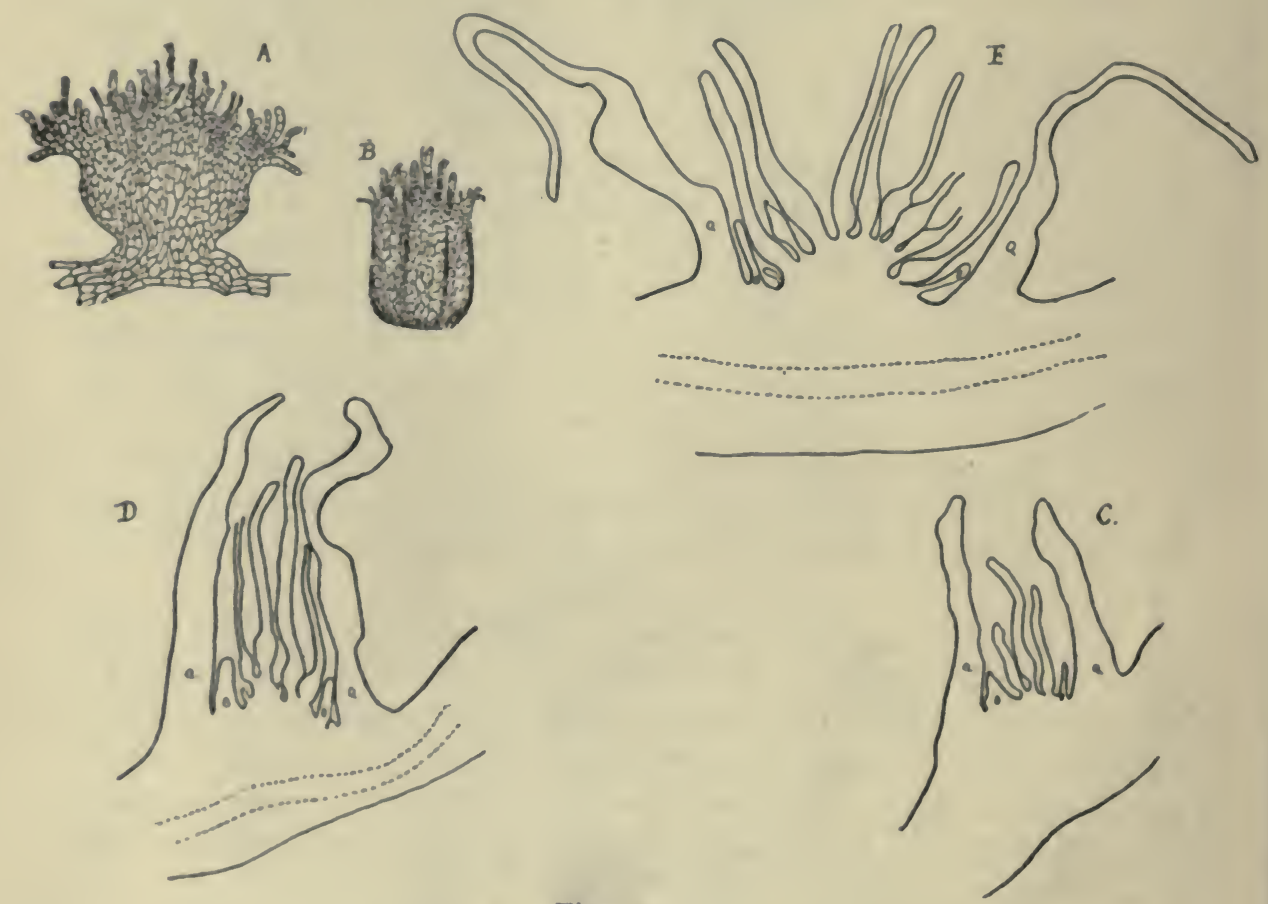

Fig. 13.

A. Archegonial receptable of $P$. radiculosa.

$B$. The same with the involucre removed.

$C$. Section of the receptacle of $P$. Zollingeri.

$D$. Section of the receptacle of $P$. Levieri.

$E$. Section of the receptacle of P. radiculosa.

$a$. Involucre; $b$, perianth. 

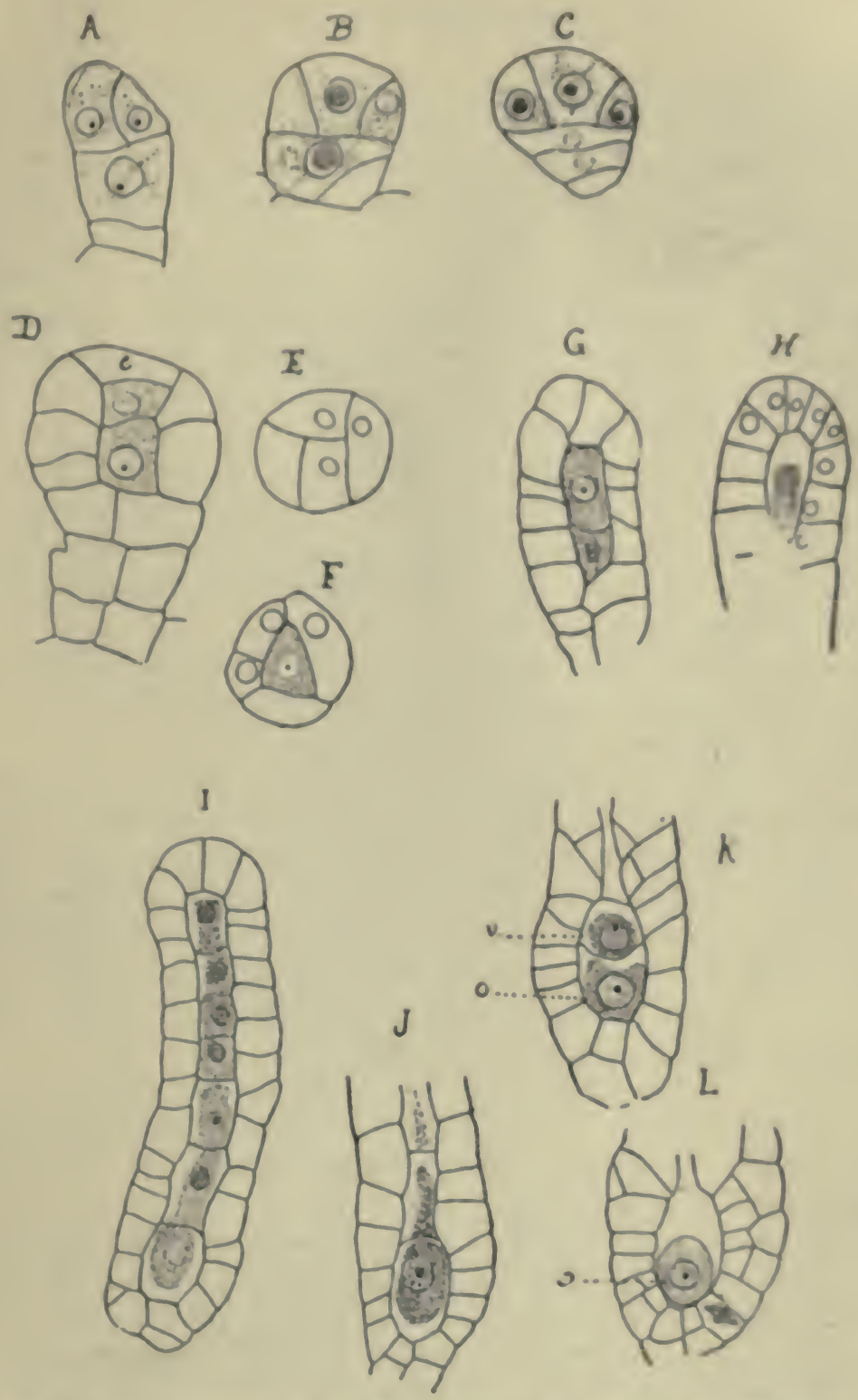

Fig. 14. Development of the Archegonium in Pallasicinia radiculoso.

$$
\text { A.F. } \times \text { \$0: G.L } \times \text { 300. }
$$

A-C. Very young stages, longituditual scctions.

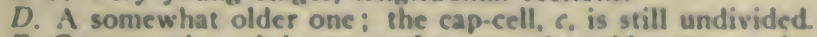

E. Cross-section of the apex of a somewhat older stage: the divisions are somewhat irregular.

F. Cross-section of a very young archegonium.

G. An older stage.

H. Apex of a still older archegonium. showing a certain amount of apical growth.

I-L. Older stages. : ventral canal-cell: O. egg-cell. 
five peripheral ones. Occasionally, as in the Marchantiales, there are six peripheral cells, but this is not usual.

The axial cell divides first by a transverse wall, and from the ventral cell arises by a subsequent division, the egg-cell, and the ventrai canal cell (Fig. 14, $K$ ). The upper of the two original axial cells next has cut off from it a terminal, or cap-cell (Fig. $14, D$ ). This cell may divide almost at once by two intersecting walls, into four cells arranged quadrant-wise when seen in cross-section; but in $P$. radiculosa this quadrant division is not always evident, and the cap-cell undergoes a considerable number of divisions which add to the upper part of the neck (Fig. 14, G, H). There is thus a limited apical growth of the neck, as well as growth due to intercalary divisions of the original neck-cells. This apical growth suggests that found in the moss-archegonium, but is much less prominent, and does not give rise to any of the canal-cells, which are all derived by division from the original neck canal-cell.

Gayet [1] states that he found a similar apical growth in a large number of liverworts, but his statements have not been confirmed by subsequent investigations. (See Campbell [I].)

The original neck canal-cell gives rise to five or six in the mature archegonium (Fig. 14,I). The neck may become very much elongated (Fig. 15), a single row of the outer cells containing as many as forty cells. The neck, in these elongated archegonia, usually becomes twisted.

Up to the time of the separation of the egg-cell and ventral canalcell, the outer part of the venter consists only of a single layer of cells (Fig. 14, I, J); but it later becomes divided into two layers by a series of periclinal divisions (Fig. 14, L).

$P$. Levieri differs mainly from $P$. radiculosa in the earlier separation of the cap-cell, and the regular division of this into quadrants, so that usually the cap-cell does not contribute to the growth in length of the archegonium-neck (Fig. 15, C-E).

The archegonia of $P$. radiculosa are larger than those of $P$. Zollingeri, and the periclinal walls in the venter seem to be formed at a rather earlier stage. $P$. Levieri resembles $P$. radiculosa in the size and form of the archegonium, but the involucre itself is more like that of $P$. Zollingeri.

After fertilization the egg develops into the embryo, about which is developed the calyptra, formed from the much enlarged venter of the archegonium. The neck of the archegonium is carried up and forms a slender process tipping the massive cylindrical calyptra. The latter is not formed exclusively of the enlarged archegonium venter, but the adjacent tissue also contributes to it. When complete the calyptra forms a sheath 
five to ten cells in thickness, enclosing the young sporophyte. With the growth of the calyptra the unfertilized archegonia are carried up, sometimes appearing almost at the summit (Fig. 22, A). These sterile archegonia may become much elongated and their neeks twisted.

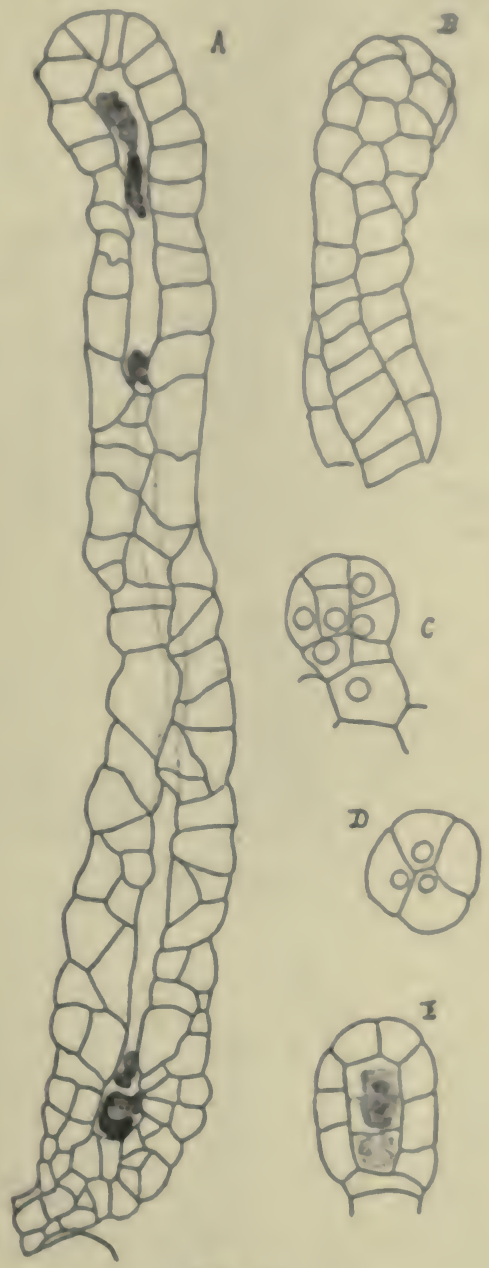

Fig. 15.

A. An old archegonium of Pallaririvio redirwlosa, with much elongated neck.

B. Surface of the upper part of a sumilar afclickonium. showing the twisting of the neck.

C. Young archegonium of $P$. L.fieri, $x 300$

D. Apex of a somewhat older one, showing quadrant arrangement of the fout ierminal cells.

E. Young archegonium of the same species. 


\section{The Embryo}

The only account of the developinent of the sporophyte in the genus Pallavicinia that we have been able to find is that of $P$.decipiens. In this species Farmer [I] gives a brief description and figures of early stages of the embryo, which seems to differ a good deal from that of $P$. Zollingeri and $P$. radiculosa, and to more nearly resemble that of Mörkia hibernica. (See Leitgeb [I], Pt. III, Pl. vi.)

While the sections of the embryos that were obtained were more or less badly shrunken, still the most important points in their development could be made out pretty well. Most of the younger stages found were of $P$. Zollingeri, but a few were also found in $P$. radiculosa and $P$. Levieri which agreed closely with the former species.

The youngest specinen that was examined consisted of two nearly equal cells, separated by a transverse wall (Fig. 16, $A$ ). The next division probably is also transverse, and arises in the upper cell, dividing the embryo into three superimposed cells, as is the case in $P$. decipiens. In the next older stage that was found, the embryo showed two large basal

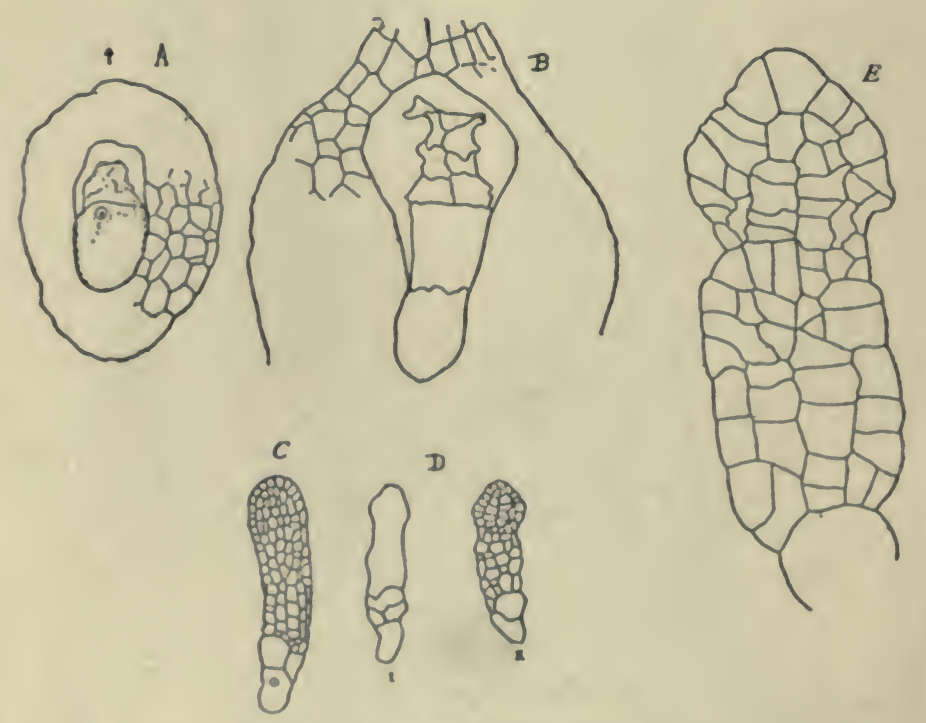

Fig. 16. Pallavicinia Zollingeri.

A. Two-celled embryo, enclosed in calyptra, $\mathrm{x} 200$.

$B$. An older embryo.

$C, D$. Older embryos, $\mathrm{x}$ about 50 .

$E$. Upper part of $D$, more highly magnified. 
cells. forming a sort of suspensor, and a terminal portion, consiating of four tiers of cells, from which all of the sporogonium except the sus. pensor is derived (Fig. 16, B). It is probable that two of the three primary cells of the embryo contribute to the mapensor. while all the rest of the sporophyte foot, acta and capuule-is derived from the terminal cell. This, however, was not positively demonurated
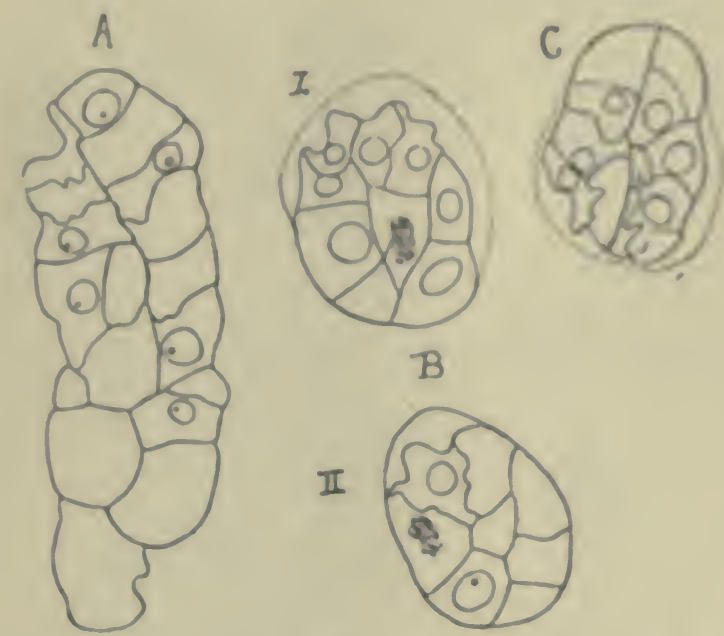

B

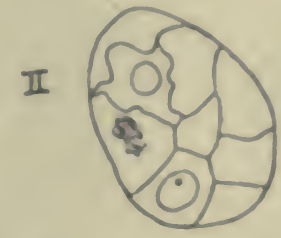

Fig. 17.

1. Longitudinal section of an embryo of Pallasicimia radiculoso, $x, 300$

$B, C$. Cross-sections of embryos of about the same age, of $P$. Lriveri The embryo shown in $B$ was cut somewhat obliquely.

The lower suspensor cell does not undergo any further division. but the upper one may divide two or three times, and there results an extremely conspicuous haustorial organ of the same character as that observed in various Jungermanniales, both acrogynous forms like Junger. mannia bicuspidata and anacrogynous types like Aneura. (Sec Leitgeb [1]. Clapp [1].)

Material was wanting for the next stages of development, but to judge from such stages as those shown in Fig. 16, C-F:, the first division in the terminal cell of the embryo is vertical, and this is followed later by a series of transwerse divisions. There is, however, a certain degree of irregularity in the divisions, as there is considerable variation in the arrangement of the cells in different embryos.

The upper part of the embryo rapidly elongates, and forms a nearly cylindrical body. the aper of which is slightly enlarged. and marks the 
beginning of the capsule, or sporogenous region. It was not possible to determine the relation of the three regions of the young sporophyte, $i$. $e$., capsule, seta, and foot, to the early divisions in the terminal cell of the embryo.

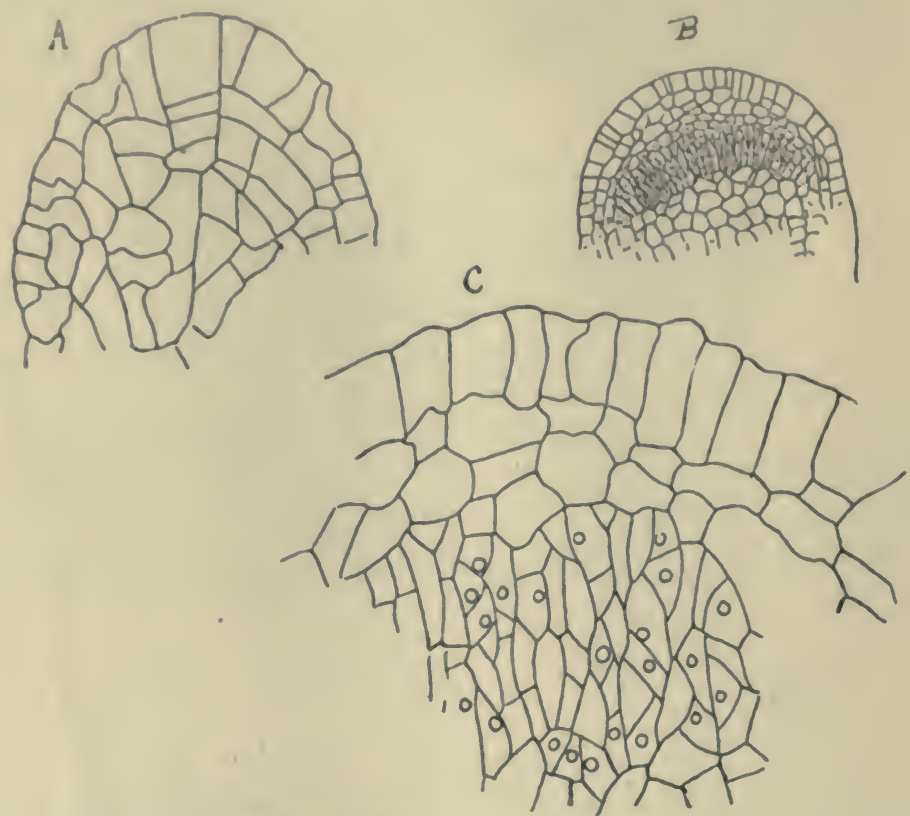

Fig. 18. Pallavicinia Zollingeri.

A. Upper part of a young sporophyte, $\times 300$.

$B$. Upper part of an older sporophyte, showing the sporogenous tissue; $x$ about 60 . $C$. Portion of $B$, more highly magnified.

In $P$. decipiens the young embryo is much shorter than in either $P$. Zollingeri or $P$. radiculosa, and more nearly resembles that of Mörkia, although more elongated than in the latter. Like Mörkia, also, the suspensor is much less conspicuous than in either $P$. Zollingeri or $P$. radiculosa.

The first periclinial walls in the terminal portion of the embryo probably determine the separation of the sporogenous tissue from the wall of the capsule (Fig. 16, E). The foot is much less clearly marked than in Mörkia, but is more evident in P. Zollingeri than it is in P. radiculosa; nor is the delimitation of the capsule and seta as definite as in either $P$. decipiens or Mörkia.

Of the three species examined, $P$. Zollingeri most nearly resembles 
Morkia in the character of the foot, which is somewhat bulbous, while in $P$. rodiculosa the foot is pointed and merges more or les gradually into the seta. P. Lecieri is somewhat intermediate between $P$. Zollingeri an 1 $P$. radiculosa in the form of the foot.
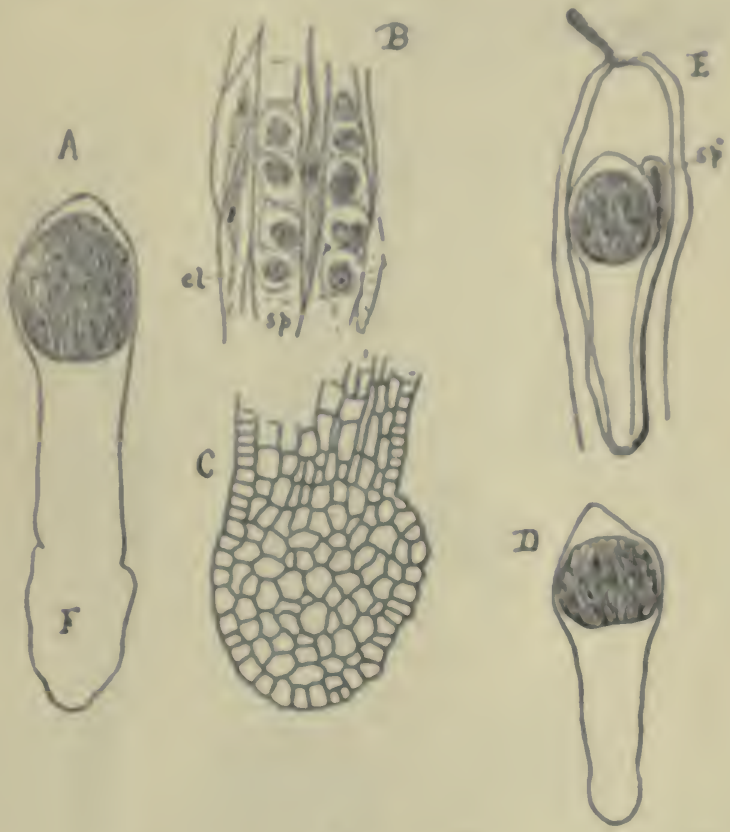

Fig. 19.

A. Section of a young sporophyte of $P$. Kollingeri, in which the young spore mother-cells and elaters are differentiated: $x 25$.

B. Part of the sporogenous region, showing spore-mother cells, sp. and young elaters, el.

C. Foot of the sporophyte.

$D, E$. Young sporophytes of $P$. Letieri, $\times 25$. In $E$ there was a second abortive sporophyte, $s p^{2}$, within the calyptra.

As the capsule develops the wall becomes clearly delimited from the sporogenous tissue within. The wall is composed of about three layers of cells throughout most of its extent. In P. Zollingeri (Fig. 18, C) the wall is three-layered also, or sometimes four-layered at the apex, the outer layer having the cells conspicuously larger than the two inner layers. In $P$. radiculosa (Fig. $21, A$ ) the wall at the apex of the capsule is much thicker, and forms a conspicuous beak. P. Levieri is intermediate in this respect also between $P$. Zollingeri and $P$. radiculosa.

The sporogenous tissue in $P$. Zollingeri forms at first a somewhat 
convex disk, which in section (Fig. 18, B) appears as a broad band of narrow cells in vertical rows. Some of these cease to divide, and later become much elongated, giving rise to the elaters; while the athers, dividing by transverse walls into rows of isodiametric cells, become the mother cells of the spores. In $P$. radiculosa the sporogenous region, even at first, is more extensive than in $P$. Zollingeri.
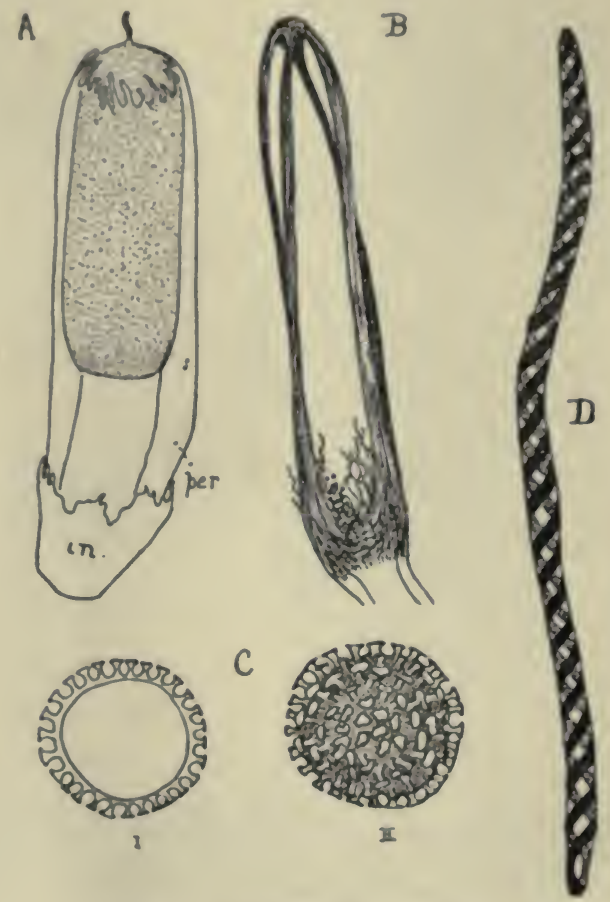

Fig. 20. Pallavicinia Zollingeri.

A. Young sporophyte still enclosed in the calyptra. in, involucre; per, perianth. $B$. Open capsule, showing the four coherent valves.

C. I, section; II, surface view of ripe spores.

D. Elater.

By the time that the perianth is fully developed the sporophyte, closely invested by the calyptra, reaches about half-way to the top, and the separation of the sporogenous tissue into the spore mother-cells and claters is plainly evident (Fig. 19, A, B). By the time that the sporophyte emerges from the perianth the spores have passed the final stage of division and are nearly mature. The material of $P$. Zollingeri did not furnish preparations showing the details of mitosis in the final stages 
of spore-division. Farmer [ 1 ] has given a full description of the nucless division in the spore mother-cells of P. decipiens, where be describes a quadripolar spindle. A similar condition has been noted in Calyculorio radiculosa (Campbell [2]); but in Pallonicinio radiculon (Fig. 21) and $P$. Levieri, which were the only species in which division-stages were en. countered, there was no certain evidence of the formation of a quadripolar spindle. As usual in the Jungermanniales, the spore mother-eells are deeply four-lobed.

The full-grown sporophyte in $P$. Zollingeri is abous $3-5 \mathrm{con}$ in heighn,
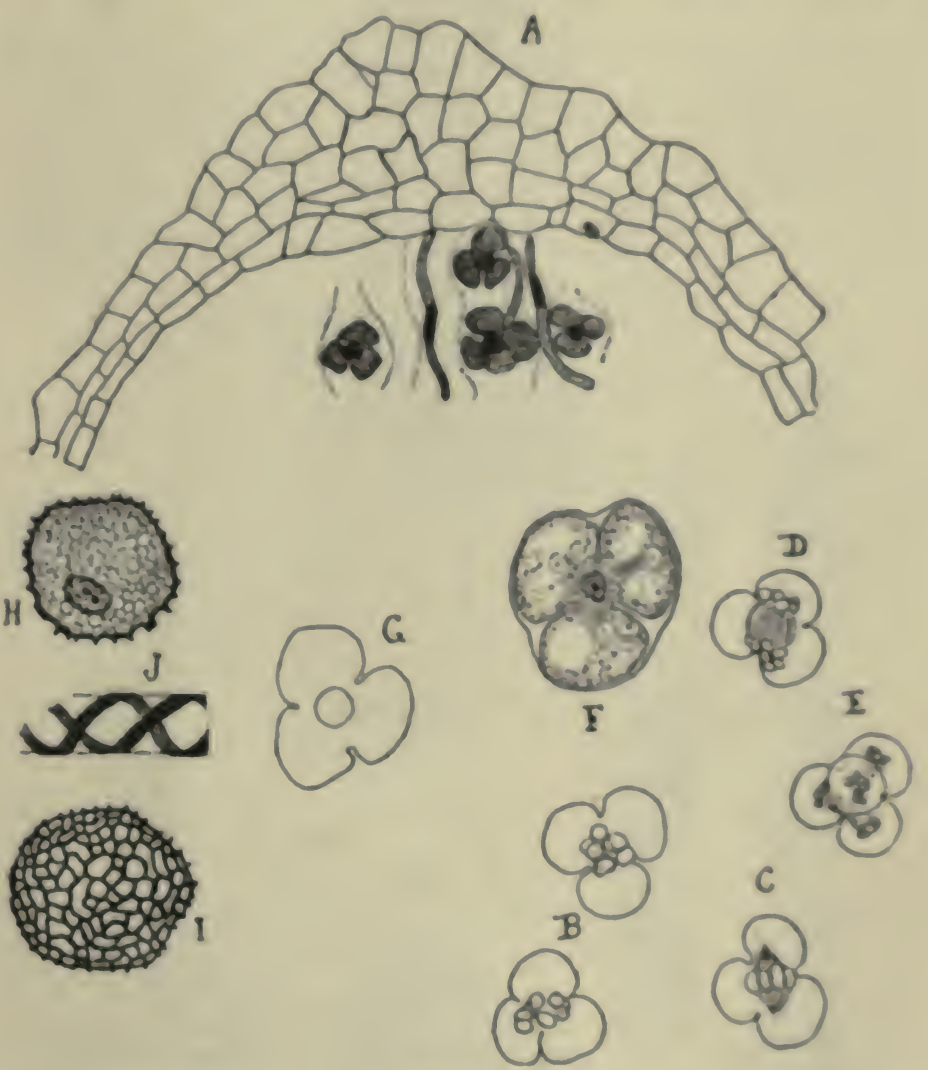

Fig. 38.

A. Upper part of the capsule of Polloricinio radiculoso, showing first stages of division in the spore mother-cells.

$B-E$. Stages in the mitosis of the spore mother-cells in $P$. rodirsloso, $x$ Gsa

$F$. Spore mother-cell of $P$. Zollingeri, $\times 640$.

$G$. Spore mother-cell of $P$. Lesien, $\times$ bsa.

$H$-J. Ripe spores and part of an elater of $P$. rodiculosa. 
the capsule, which is elongated oval in outline, being about $4 \mathrm{~mm}$. in length by $1.5 \mathrm{~mm}$. in breadth. The ripe capsule opens by four longitudinal slits, but the apical cap remains entire, so that the four valves between the slits remain together at the apex (Fig. 20, B). The ripe spores (Fig. 20, $C$ ) measure about $14 \mu$ in diameter, and the outer surface is covered with closely set blunt papillae, with somewhat expanded outer

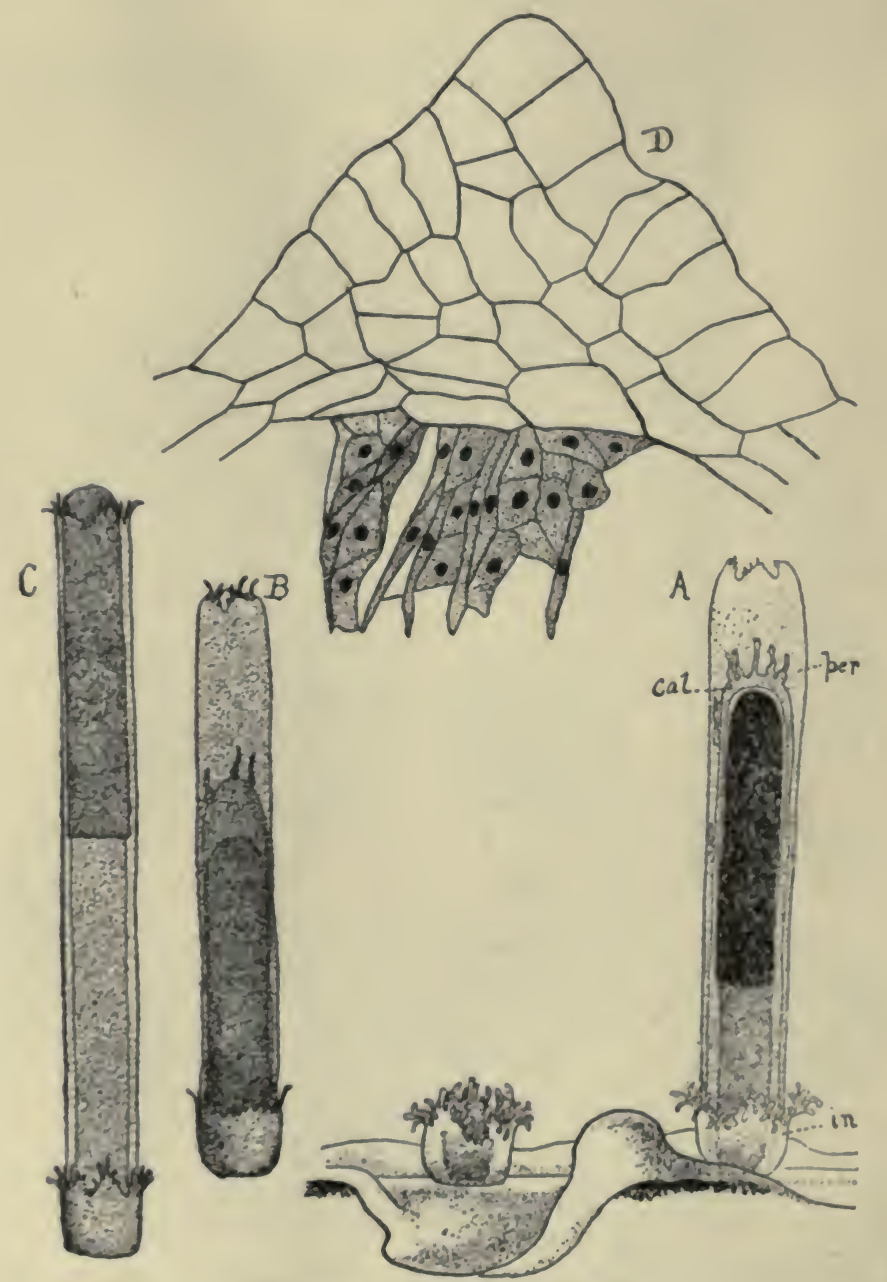

Fig. 22. Pallavicinia Levieri.

$A-C$. Young sporophytes. $A$ and $B$ still included within the calyptra; $C$, after breaking through.

$D$. Section of upper part of the capsule, highly magnified. 
ends. The elaters have two spiral bands. The one figured, which measured $150 \mu$ in length, was somewhat shorter than the majority of them.

The mature sporophyte of $P$. radiculosa differs from that of $\boldsymbol{P}$. Zollingeri in its shorter seta, which, according to Schiffner $[1]$, is only $15-20 \mathrm{~mm}$. in length. The capmule, however, is much longer than is $P$. Zollingeri, but almost perfectly cylindrical in form. Mcarcely esceoding in width the seta (Fig. 23. D). As already stated, also, the apex as conspicuously pointed. It oprens in the saste way, by four narrow ralves. united at the apex. Except at the pointed apex, the wall of the capale is composed of three layers of cells, of which the outer one has the cellwalls uniformly thickened, and dark colored. The markings on the ripe spores form a network of delicate ridges, much like those in Fonmmbronia, but quite difierent from those found in Pallatricimia Zolliacer (Fig. $21, I, J$ ). The ripe spores are $12-15 \mu$ in diameter, and the elacers often measure about $225 \mu$ in length.
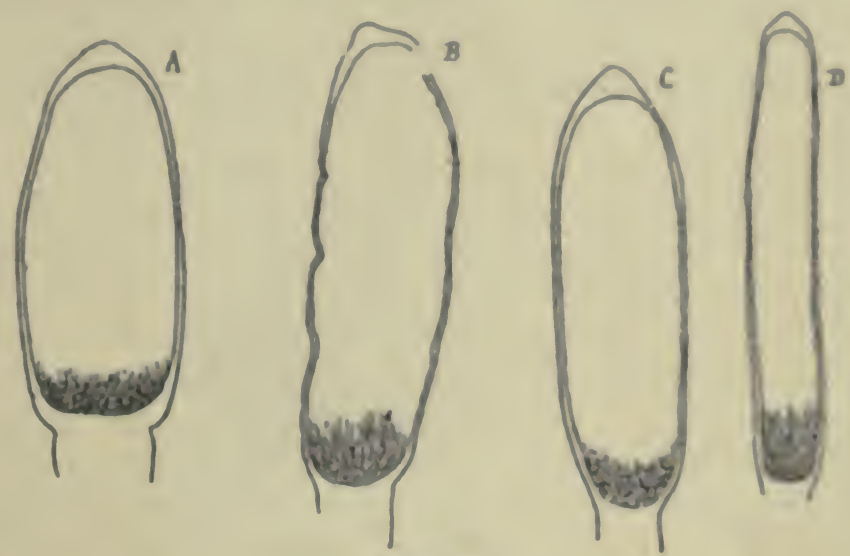

Fig. 23.

Sections of the eapsules of $P$. Zollingeri, $A: P$. Lecieri, $B ; P$, indics, $C$ : $P$, radicwloso, $D . B$ and $D$ are not fully grown. $A-C, \times 18: D, \times 10$.

\section{Spore Division}

Long before any sign of the final nuclear division in the sporemother-cell can be seen the cell becomes deeply four-lobed, as in all Jungermanniales. The mother cell in P. Zollingeri (Fig. 21, L.). is decidedly larger than in $P$. radiculoso, but its nucleus is smaller. Traces of what looked like the quadripolar spindle described by Farmer in $P$. 
decipiens could be sometimes seen, and at the extremity of the rays of the spindle was a body which may have been a centrosphere. The material, however, was not very well stained, and the nature of these bodies was not perfectly clear. As no stages of mitosis were seen, it remains to be seen whether the chrmosomes are four in number, as in $P$. decipiens (Farmer [ $[1]$ ), or eight, as in $P$. radiculosa.

In the latter species (Fig. $21, A, E$ ), there are eight chromosones,thick, somewhat kidney-shaped bodies; and instead of the quadripolar spindle there is a conspicuous bipolar spindle of the usual form. The chromosomes divide and arrange themselves in two groups which move to the poles of the spindle, where without assuming the form of a resting nucleus they divide again, and a second bipolar spindle is formed. It was supposed that as the result of a reduction division there would be only four chromosomes in the young spores; but there is no question that eight are present in most cases, at least, and none were seen where the number was four. A similar condition was found by Farmer in $P$. decipiens, and it is also the case in Calycularia radiculosa. (See Campbell [2].)

It still remains to be seen where the reduction division occurs in these liverworts. 


\section{SUMMARY}

1. The thallus in the two sections of the genus Pallavicinia differs in two respects. In the section Eupallavicinia, the wings are tait ofe cell thick throughout, while in Mittenia the midrib merzes grabally into the wings, as is the case in Morkia and Calycularia. In Mittenia also, shere is a marked difference between the prostrate, rhizome-like portioe of the trallus and the upright fan-shaped green branches. In the laiter also. the formation of adventitious branches from the rhizome is more common than in the species of Eupallavicinia.

2. The apical cell in the three species considered in this paper is a two-sided one. like that of Aneura or Metzgeria. These species Alfier in this respect from $P$. decifiens, where the apical cell is a thret-dided prism (Farmer [1]). Pallariciosin cylindrica (Campbell [1]). may have a two-sided apical cell, but more commonly it appears oblong when woen is horizontal section. P. (Blystia) Lyellii. accorling to Ifrigeth $[1]$ that a two-sided apical cell.

3. The hooked marginal teeth. found in Mittenia. are probably coms. parable to the leaf-like lobes of certain species of Symphyogyra, and hike them bear a definite relation to the segments of the apieal cell.

4. The position of the antheridia in the three species studied differt somewhat from the descriptions given by Schiffner [2]. In P. (Mistomia) Zollingeri they cover the whole surface of the midrib, as they do in Mör. kia. In the related species, $P$. decipiens. they are said by Famer [ 1$]$ to form a row on each side of the midrib. In $P$. Leiveri they occur in a row on each side of the midrib, and not on its upper side. In $P$. radiculesa the presence of sterile areas between the groups of antheridia seems to have been overlooked by previous students of this species.

5. The development of the antheridium is much alike in all the species, and conforms to the usual type found in the Jungermarniales.

6. The spermatogenesis corresponds to that found in other Hepaticae. A delicate membrane separates the pairs of spermatocytes, as in Fossombronia and Calycularia. It is possible that a "Nebenkörper," like that described for Marchantia (Ikeno (1)) and for Fossombronia (Humphrey (1]) may be present. but this was not certainly dennonstrated. Wootbum [1] believes that such a body is not present in the spermatozoid. The number of chromosomes is probably eight. 
7. Of the three species examined, $P$. Zollingeri has the smallest archegonial receptacle, and $P$. radiculosa the largest. The archegonium of $P$. radiculosa shows a limited apical growth due to the activity of the cover-cells.

8. The embryo of Pallavicinia agrees in many ways with that of other Anacrogynac that have been studied. It is perhaps most like that of Aneura in the development of a very large haustaurial organ, or suspensor. In this respect the species under consideration seem to differ a good deal from $P$. decipiens, and from Mörkia. Of the three species, $P$. Zollingeri is nearest to Mörkia in the form of the capsule and the larger foot.

9. The species all agree in the structure of the capsule, which has a more or less conspicuous terminal beak or pad, which remains intact, so that the four valves of the open sporogonium remain attached to each other at the apex, and the capsule opens by four longitudinal slits. The beak is best developed in $P$. radiculosa, which has a much more elongated capsule than the other species. In its much shorter and relatively broader capsule, $P$. Zollingeri is more like Mörkia or Calycularia. P. Zollingeri is also like the latter in the tuberculate spores. In $P$. radiculosa and $P$. Levieri the spores are reticulately marked. 


\section{CONCLUSION}

To judge from the foregoing study of Pallavicinia, P. Zollingeri is in some respects more like Môrkia than it is like the other apecies of Pallavicinia that were examined. This is true of the thallus, which has a broad. indefinite midrib, merging gradually into the wings, inutead of the shasply defined midrib, and thin wings of Eupallavicinia. The conducting tisoue, however, is well developed. The sporophyse, alwo, appreaches in turm that of Môrkia. Whether these differences, combined with the very dif. ferent habit, are sufficient to warrant the retention of the generic sume Mittenia for the dendroid species of Pallavicinia, may be poestioned : turt on the whole we are inclined to think this is justified and the menters of the section Eupallavicinia might properly be transferred to Blytia

The inter-relationships of the Jungermanniales are very perplexiage. Cavers [2] in his recent excellent sunmary of the subject points out that there is practically no constant point of difference between the two farmilies Blyttiaceae and Aneuraceae (Schiffner's families Metzgerioidcae and Leptotheceac). Cavers places in the first family the genera Blyrria (Pallavicinia), Mörkia, Symphyogyna and Makinoa. In the latter ase also included four genera, Aneura, Metzgeria, Umbraculum and Podomitritum. The two latter are often united into a single genus, Hymenophyzon, bat they are abundantly distinct and probably not closely related. Umbraculum is undoubtedly related to Metzgeria, but Podomitrium, except for the position of the reproductive organs, is hardly distinguishable from Blyttia, either in the structure of the thallus or that of the sporophyte. $P$. malaccense, for example, a species common in Westem Borneo, is absolutely indistinguishable from a typical Blyttia, except for the position of the reproductive organs upon short ventral branches, instead of upon the ordinary shoots. We believe that Podomitrium should be placed in the Blyttiaceac, rather than in the Aneuraceac, supposing it seems best to retain these two families, and not unite them into a single one as Cavers suggests.

The production of the reproductive organs upon special branches. which appears to be the only constant difference between the Aneuraceac and Blyttiaceac, seems hardly of sufficient importance to warrant the establishment of two families, especially as, except for the small size of the fertile branches, they do not differ essentially from the ordinary shoots upon which the reproductive organs oceur in the Blyttiaceae. 
Among the genera about which there has been some controversy is Calycularia. C. radiculosa, an interesting species of the Malayan region, was recently studied (Campbell [2]), and it was demonstrated that it has much in comrnon with Blyttia and Mörkia, with which it is doubtless related. Schiffner $\{3\}$ even thinks it should be transferred to the genus Mörkia and entirely separated from the other members of the genus Calycularia.

While it is still too soon to propose a definitive classification of the thallose Jungermanniales, it may be said that so far as the two families Aneuraceae and Blyttiaceae are concerned, the differences between them are not of sufficient importance to warrant the establishment of two families. 


\section{BIBLIOGRAPIHY}

BowEx, F. O.-The Origin of a Land Fora. Macmillan, sgok.

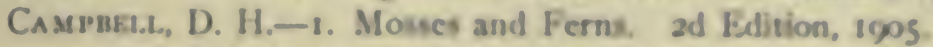

2. The Morphology and Symentatic Position of Calyculorio nadiculosu (Steph.). Stanford University. 1913.

Cavers. I:-1. Notes on Yorkshire Bryophyzes, II: Palloricieia Flocon «iand. The Naturalist, 1003 .

2. The Inter-relationships of the Bryophyta. Nre Phytolecist, IX. $1910,6.7$.

Cuamerranx, C. J.-Mitosis in Pellia. Boponical Coeste, XXXVI. 1903.

Ciapr, Grace 1.- The Life History of Anewra pinguis. Bosonical Casefte, LIV, 1912.

Davis, B. M.-Nuclear Studies on Pellia. Annals of Botany. XV. 19001.

Evass, A. W.-An Arrangement of the Genera of the Hepaticac. Transactions of the Connecticus Academy, VIII, 1892.

Farmer, J. B.-1. On Pallasicinia decipiens. Annals of Bebany, VIII. 1904.

2. The Quadripolar Spindle in the Spore Mother-eell of Pellia epiphylla. Ibid., XV, 1901.

Gayer. L. A.-Récherelies sur le développenent de l'archégone chez les Muscinées. Annales des Sciences Naburelles, Bur \&e série. tome 3. 1897 .

Gofmet, K.-1. Organography of Plants, Part 2. Oxford, 1905.

2. Archegoniatenstudien, X. Beitrăge zů Kenนtsiss auvıralischę und neuseelandischer Bryophyten. Flora, XCVI. spo6.

HoraEtste., W.-The Higher Cryptogamia. 1862.

Husrukf. H. B.-The Development of Fossombronia longiresa. Annals of Bopany, XX. 1906.

IkFvo, S.-Die Spermatogenese von Marchantia polymorpla Peiheit zum Bot. Centralblass, XV, 1903.

LEClerc dU SAmLos.-Récherches sur le développernent dis iponogone des Hèpatiques. Annoles des Sriences Napurrilles, ac séric. tome 11.1885 .

LeıtGeB, H.-Untersuchungen über die Lebermoose, Heft III. Jema, 1877 . 
Mıяке, K.-Makinoa, a new Genus of Hepaticae. Botanical Magazine, Tokyo, XIII, I899.

Schiffoer.-1. Hepaticae. Engler und Prantl, Die natürlichen Pflanzenfamilien.

2. Die Hepaticae der Flora von Buitenzorg. Leiden, 1900.

3. On Calycularia. Osterreichische Botanische Zeitschrift, 1901.

Stepraxı, F.-Species Hepaticarum. Mémoires de L'Herbier Boissier, 1900.

Tansley, A. S. and CHick, E.-Notes on the Conducting Tissue System in Bryophyta. Annals of Botany, XV, Igor.

Wulson, M.-Spermatogenesis in the Bryophyta. Annals of Botany, XXV, I9II.

Woodburn, W. L.-Studies in Spermatogenesis. Annals of Botany, XXV, 1911. 
$45^{\prime}$

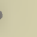





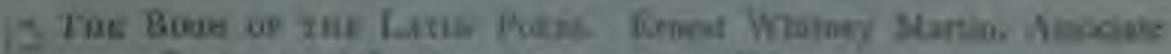

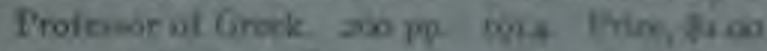

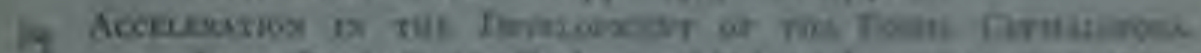

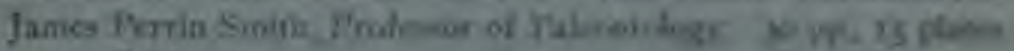
tots Irice, 736

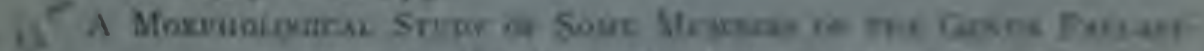

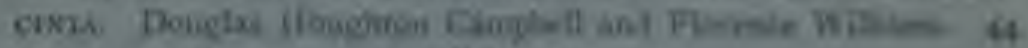

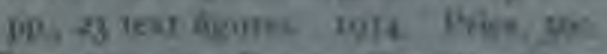

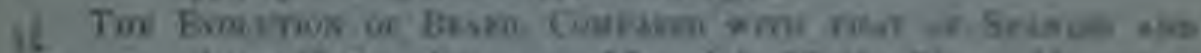

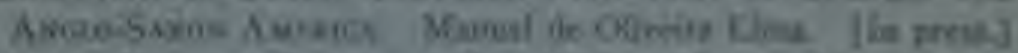
1)

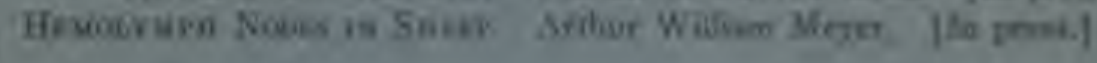




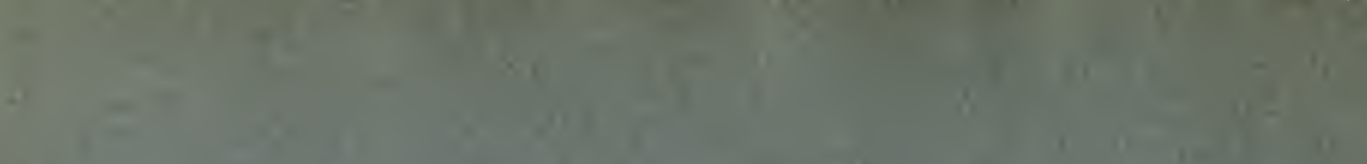

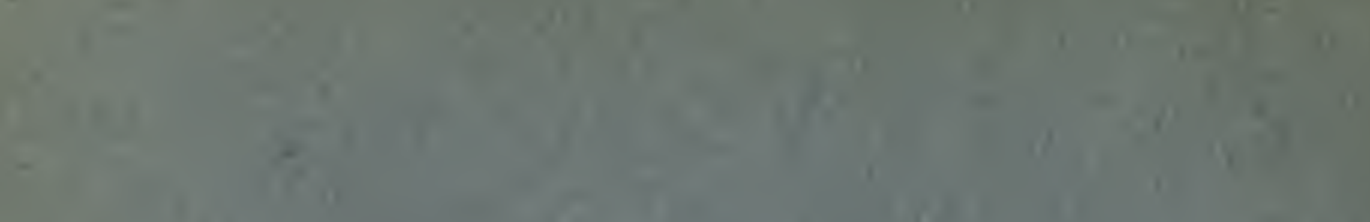

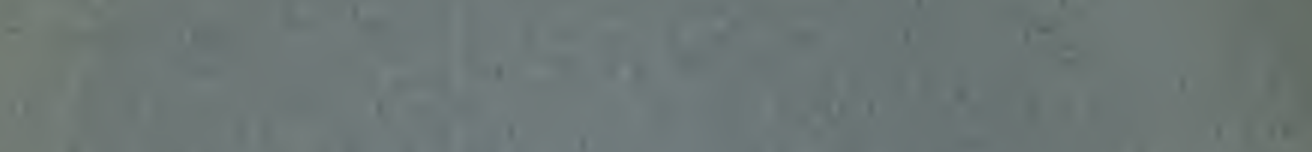

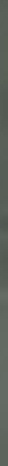

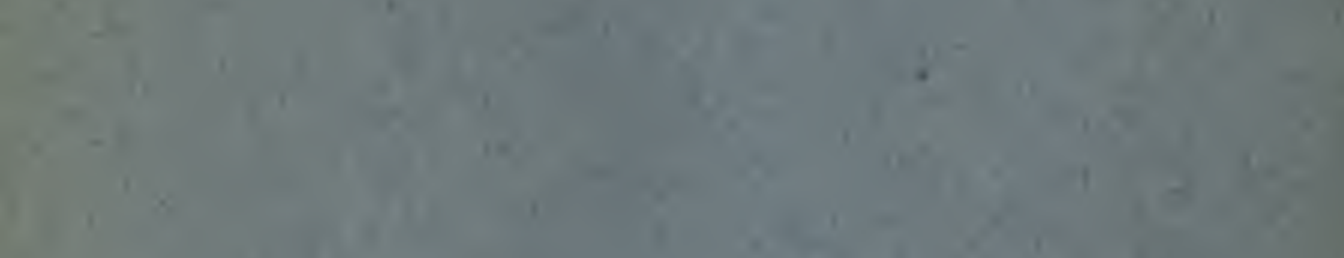

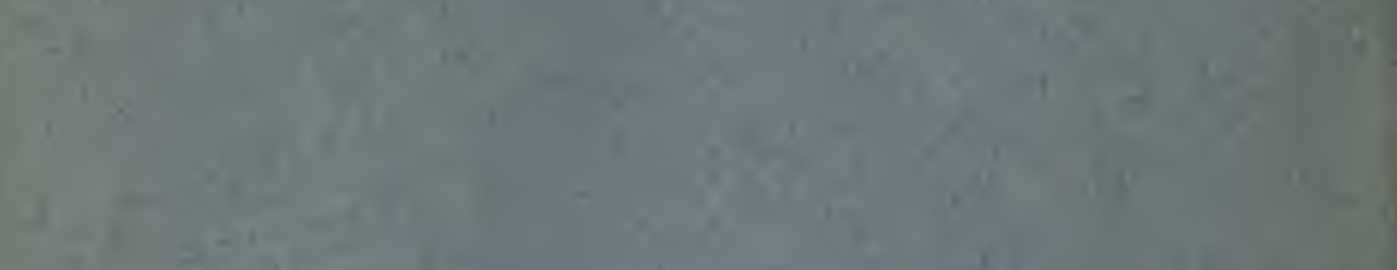

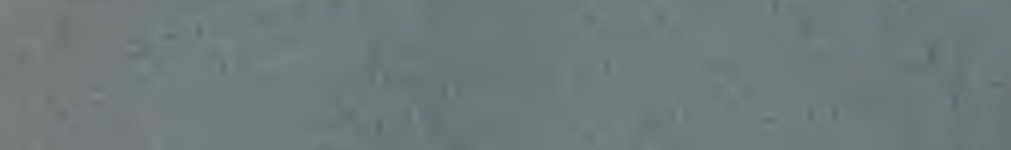

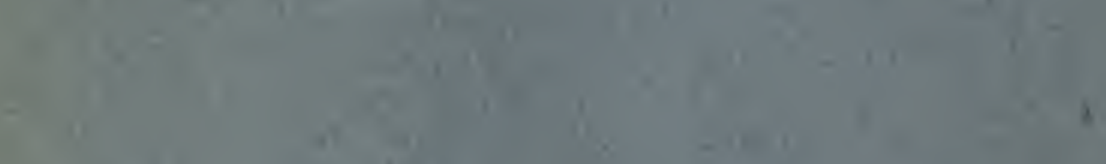

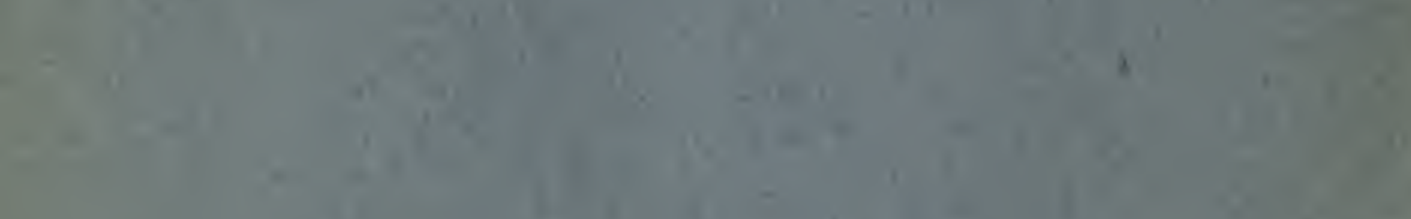

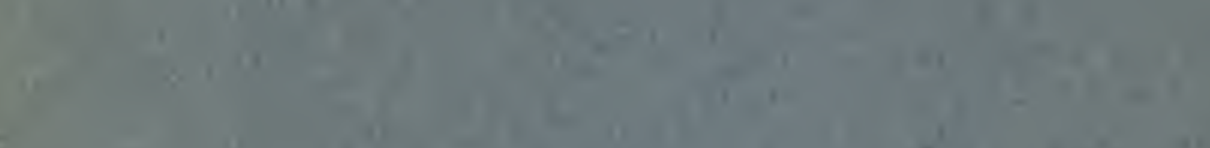

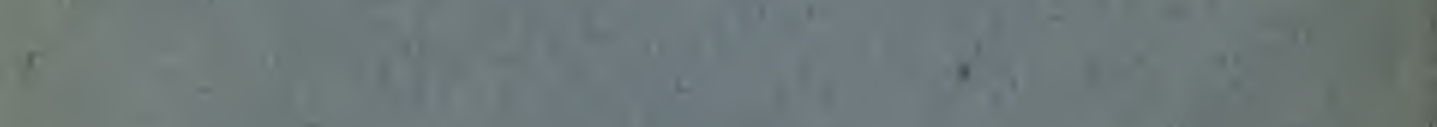

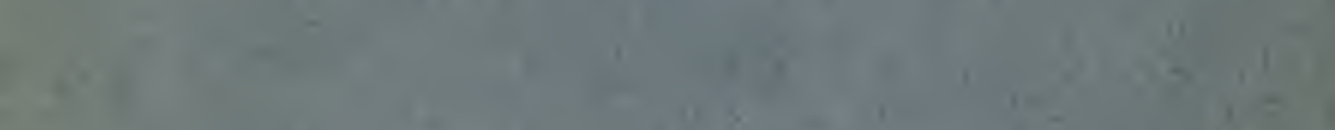

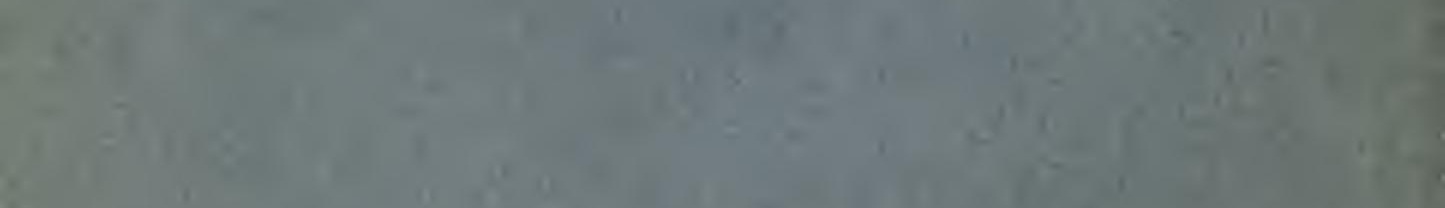

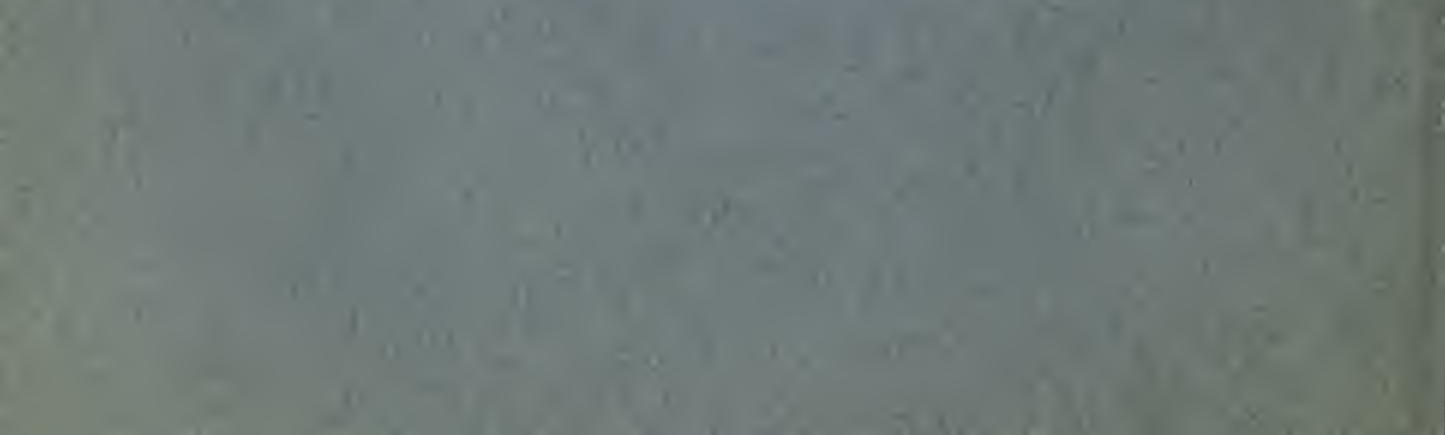








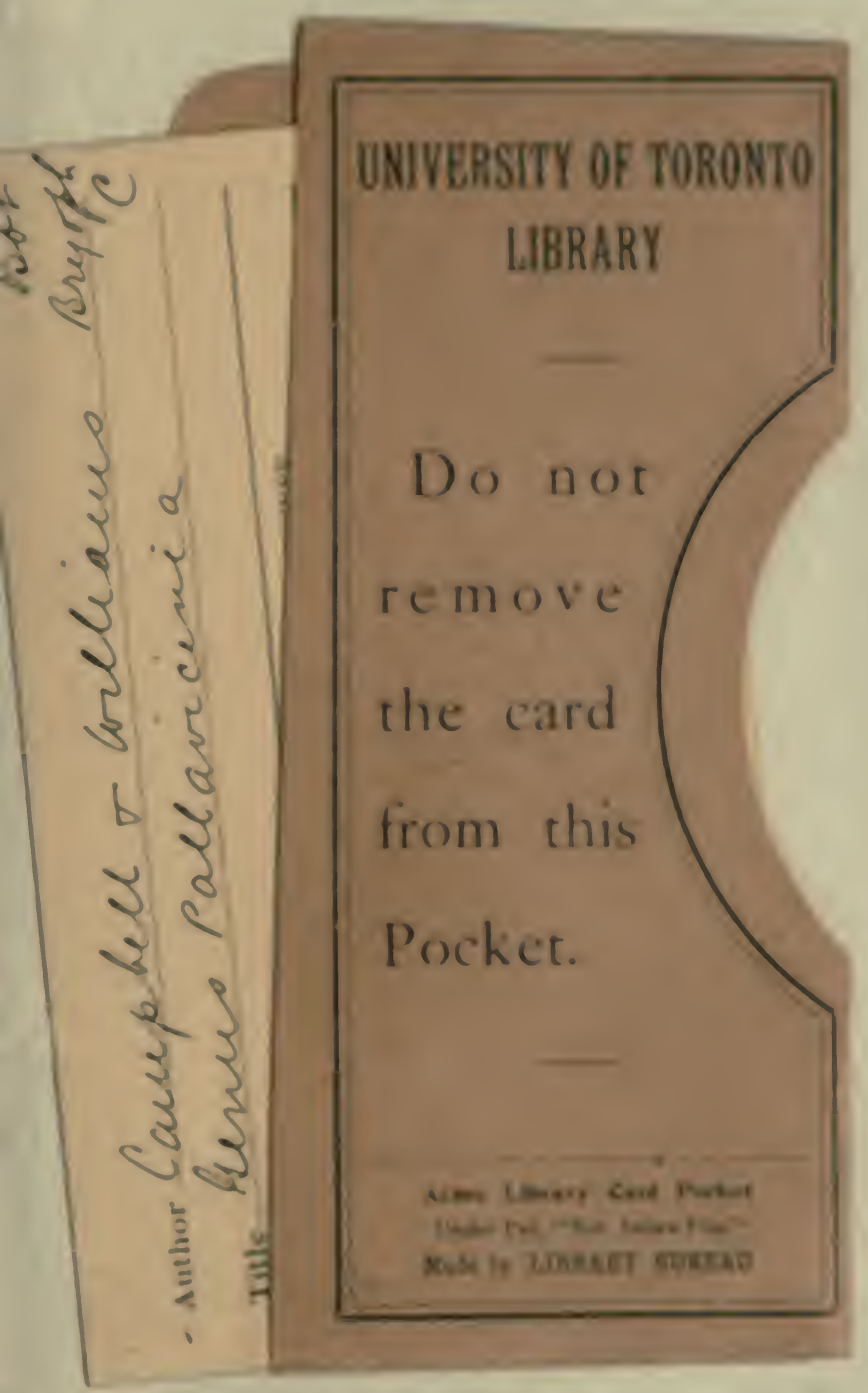


